NATL INST. OF STAND \& TECH

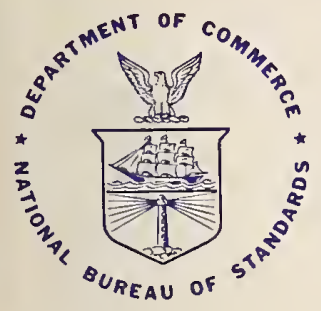

NBS TECHNICAL NOTE 1201

U.S. DEPARTMENT OF COMMERCE/National Bureau of Standards

\title{
Weatherization of Residences: Criteria for Retrofit Materials and Products
}

\section{$Q C$ \\ 100}

.05753

1201

1984 
he National Bureau of Standards' was established by an act of Congress on March 3, 1901. The

Bureau's overall goal is to strengthen and advance the nation's science and technology and facilitate their effective application for public benefit. To this end, the Bureau conducts research and provides: (1) a basis for the nation's physical measurement system, (2) scientific and technological services for industry and government, (3) a technical basis for equity in trade, and (4) technical services to promote public safety. The Bureau's technical work is performed by the National Measurement Laboratory, the National Engineering Laboratory, the Institute for Computer Sciences and Technology, and the Center for Materials Science.

\section{The National Measurement Laboratory}

Provides the national system of physical and chemical measurement; coordinates the system with measurement systems of other nations and furnishes essential services leading to accurate and uniform physical and chemical measurement throughout the Nation's scientific community, industry, and commerce; provides advisory and research services to other Government agencies; conducts physical and chemical research; develops, produces, and distributes Standard Reference Materials; and provides calibration services. The Laboratory consists of the following centers:
- Basic Standards ${ }^{2}$

- Radiation Research

- Chemical Physics

- Analytical Chemistry

\section{The National Engineering Laboratory}

Provides technology and technical services to the public and private sectors to address national needs and to solve national problems; conducts research in engineering and applied science in support of these efforts; builds and maintains competence in the necessary disciplines required to carry out this research and technical service; develops engineering data and measurement capabilities; provides engineering measurement traceability services; develops test methods and proposes engineering standards and code changes; develops and proposes new engineering practices; and develops and improves

mechanisms to transfer results of its research to the ultimate user. The Laboratory consists of the following centers:

\section{The Institute for Computer Sciences and Technology}

Conducts research and provides scientific and technical services to aid Federal agencies in the selection, acquisition, application, and use of computer technology to improve effectiveness and economy in Government operations in accordance with Public Law 89-306 (40 U.S.C. 759), relevant Executive Orders, and other directives; carries out this mission by managing the Federal Information Processing Standards Program, developing Federal ADP standards guidelines, and managing Federal participation in ADP voluntary standardization activities; provides scientific and technological advisory services and assistance to Federal agencies; and provides the technical foundation for computer-related policies of the Federal Government. The Institute consists of the following centers:
- Applied Mathematics

- Electronics and Electrical Engineering ${ }^{2}$

- Manufacturing Engineering

- Building Technology

- Fire Research

- Chemical Engineering 2

\section{The Center for Materials Science}

Conducts research and provides measurements, data, standards, reference materials, quantitative understanding and other technical information fundamental to the processing, structure, properties and performance of materials; addresses the scientific basis for new advanced materials technologies; plans research around cross-country scientific themes such as nondestructive evaluation and phase diagram development; oversees Bureau-wide technical programs in nuclear reactor radiation research and nondestructive evalualion; and broadly disseminates generic technical information resulting from its programs. The Center consists of the following Divisions:
- Programming Science and Technology

- Computer Systems Engineering
- Inorganic Materials

- Fracture and Deformation ${ }^{3}$

- Polymers

- Metallurgy

- Reactor Radiation 


\section{Weatherization of Residences: Criteria for Retrofit Materials and Products}

Walter J. Rossiter, Jr. and Robert G. Mathey, Editors

Center for Building Technology

Building Materials Division

National Engineering Laboratory

National Bureau of Standards

Washington, DC 20234

Sponsored by:

Department of Energy

Office of Weatherization Assistance

1000 Independence Avenue, SW

Washington, DC 20585

Supersedes NBS Technical Note 982

August 1984

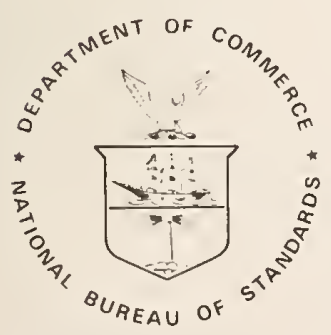

U.S. DEPARTMENT OF COMMERCE, Malcolm Baldrige, Secretary

NATIONAL BUREAU OF STANDARDS, Ernest Ambler, Director 
National Bureau of Standards Technical Note 1201

Natl. Bur. Stand. (U.S.), Tech. Note 1201, 68 pages (Aug. 1984) CODEN: NBTNAE 


\section{ABSTRACT}

The Department of Energy (DoE) requested the National Bureau of Standards to review and update criteria for materials and products to be included in the DoE Weatherization Assistance Program. This program was established by Congressional legislation in 1976 and was directed toward providing financial assistance to low-income individuals for retrofitting residences to conserve energy. In most cases, only energy-saving materials and products for which standards and specifications are available are to be included in the Program. In late 1983 DoE proposed rule changes to the Program which made it necessary to update existing criteria and establish, as appropriate, new criteria.

Criteria are given for retrofit materials and products included in the DoE Weatherization Assistance Program. These materials and products are thermal insulation, storm windows and doors, replacement windows and doors, caulks and sealants, weatherstripping, vapor retarders, clock thermostats, and replacement glazing. The criteria are based on a consideration of factors such as thermal performance, fire safety, durability, quality, conformance to building codes, use, and ease of installation.

The retrofit materials and products are listed by generic type along with pertinent standards and specifications. Precautions to be followed during their installation are also given for each of the items. Fire safety requirements for thermal insulations are recommended with regard to the use and locations where they are installed.

Key words: caulks and sealants; clock thermostats; energy conservation; fire safety; insulation; replacement glazing; replacement windows and doors; retrofitting; storm windows and doors; vapor retarders; weatherization; weatherstripping. 


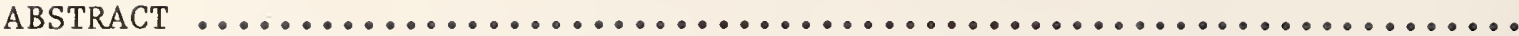

ACKNOWLEDGMENTS ...........................................

SI CONVERSION UNITS .......................................

LIST OF TABLES ............................................

LIST OF FIGURES

ii

$\mathrm{v}$

$\mathrm{vi}$

viii

1. INTRODUCTION $\ldots \ldots \ldots \ldots \ldots \ldots \ldots \ldots \ldots \ldots \ldots \ldots \ldots \ldots \ldots \ldots \ldots \ldots \ldots \ldots \ldots \ldots \ldots \ldots$

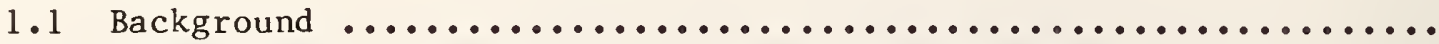

1.2 Weatherization Assistance for Low-Income Persons ...........

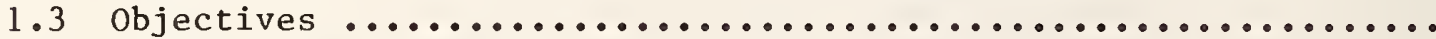

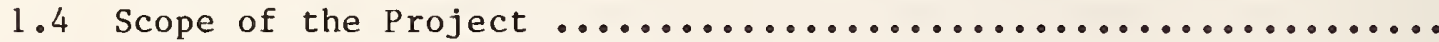

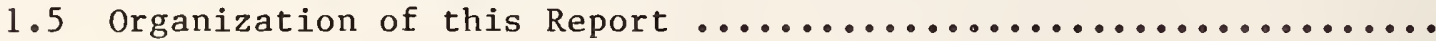

2. RECOMMENDED CRITERIA FOR MATERIALS AND PRODUCTS INCLUDED IN THE DoE WEATHERIZATION ASSISTANCE PROGRAM .....................

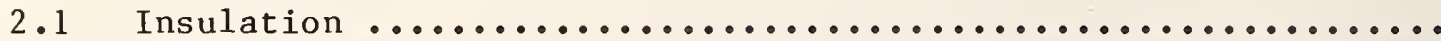
7

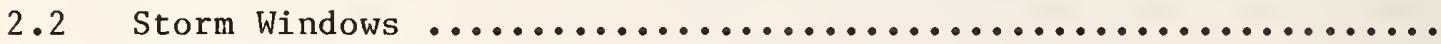

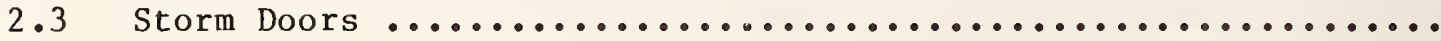

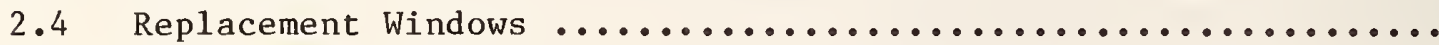

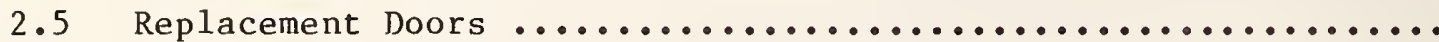

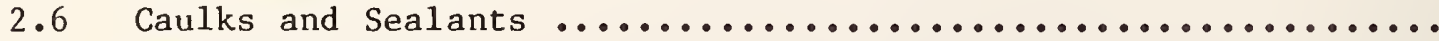

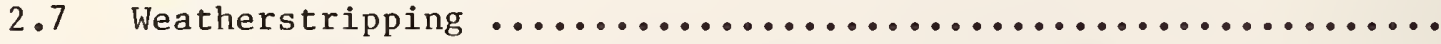

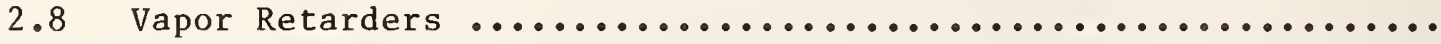

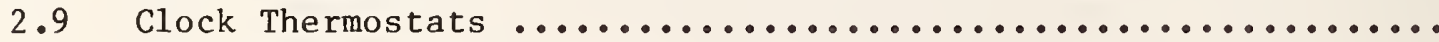

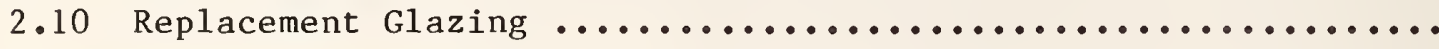

3. InSTALLATION PRECAUTIONS .............................. 42

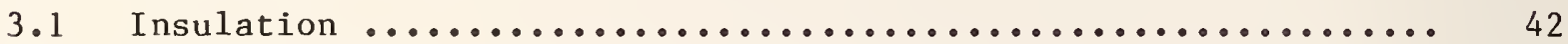

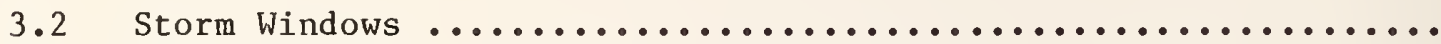

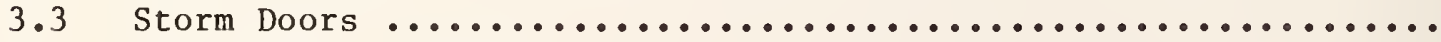

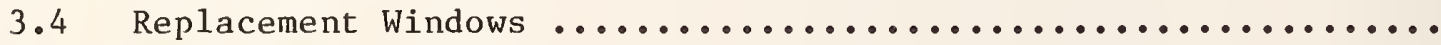

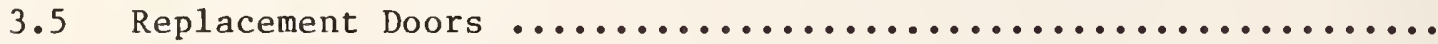

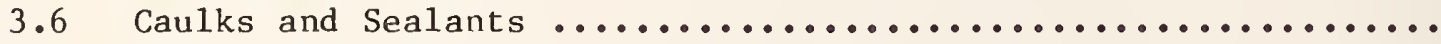

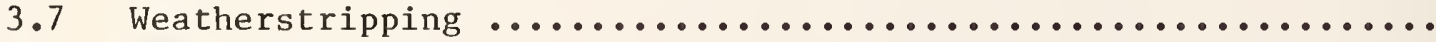

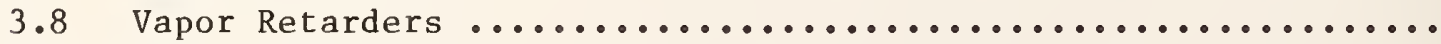

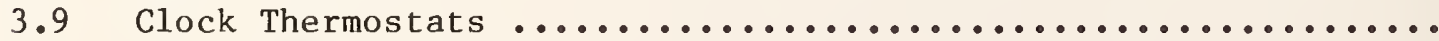

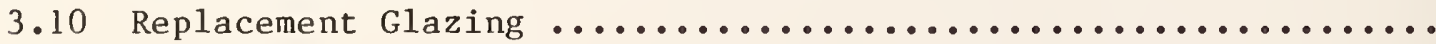

4. REFERENCES ...................................... 50

APPENDIX A. STANDARDS AND SPECIFICATIONS CITED IN THIS REPORT ........ A-1 


\section{ACKNOWLEDGMENTS}

The editors wish to thank the researchers in the Center for Building Technology (CBT) and Center for Fire Research (CFR) at the National Bureau of Standards who assisted and participated in preparing the criteria and information in this report. CBT research staff members were Douglas Burch, McClure Godette, James Kao, and Steven Treado. CFR research staff were Sanford Davis and Daniel Gross. Criteria and information for each of the specific retrofit materials and products discussed in the report were provided as follows:

- Insulation--D. Burch, S. Davis, D. Gross, R. Mathey, and W. Rossiter

- Fire Safety Requirements for Insulations--S. Davis and D. Gross

- Storm Doors and Windows and Replacement Doors and Windows--D. Burch, R. Mathey, W. Rossiter, and S. Treado

- Caulks and Sealants--M. Godette and W. Rossiter

- Weatherstripping--W. Rossiter

- Vapor Retarders--D. Burch and W. Rossiter

- Clock Thermostats--J. Kao and W. Rossiter

- Replacement Glazing--R. Mathey and W. Rossiter

This report was sponsored by the Department of Energy, Office of Weatherization Assistance, under the direction of Mr. Joseph P. Flynn, Jr. Technical coordination with the Office of Weatherization Assistance was provided by Ms. Sandra S. Monje whose assistance and encouragement the editors gratefully acknowledge.

Special thanks are expressed to Mr. Douglas M. Burch, NBS, for his thorough review and critique of NBS Technical Note 982 and for his many valuable comments and suggestions for revising the criteria for retrofit materials and products.

This report is, in part, a revision of NBS Technical Note 982. A number of CBT and CFR research staff contributed to the preparation of NBS Technical Note 982. Since some of the information included in this present report was previously published in NBS Technical Note 982, the editors again wish to acknowledge their colleagues who assited in its preparation. Those individuals were Belinda L. Collins, David A. Didion, Daniel Gross, S. Robert Hastings, Arthur Hockman, Bradley A. Peavy, John S. Stroik, and Jenkins Washington.

The assitance of Ulesia E. Gray, Charity Lancaster, and Mary L. Ramsburg in typing and editing this manuscript is gratefully appreciated. 


\section{SI CONVERSION UNITS}

In view of the presently-accepted practice in this country in this technological area, common U.S. units of measurement have been used throughout this paper. In recognition of the position of the U.S.A. as a signatory to the General Conference on Weights and Measures, which gave official status to the metric SI system of units in 1960, we assist readers interested in making use of the coherent system of SI units by giving conversion factors applicable to U.S. units used in this paper.

\section{Length}

1 in $=0.0254$ meter* $(\mathrm{m})$

$1 \mathrm{ft}=0.3048$ meter* $(\mathrm{m})$

Area

1 in ${ }^{2}=0.000645$ square meter $\left(\mathrm{m}^{2}\right)$

$1 \mathrm{ft}^{2}=0.0929$ square meter $\left(\mathrm{m}^{2}\right)$

\section{Volume}

1 in $^{3}=0.0000164$ cubic meter $\left(\mathrm{m}^{3}\right)$

$1 \mathrm{ft}^{3}=0.0283$ cubic meter $\left(\mathrm{m}^{3}\right)$

Mass

$11 b=0.454$ kilogram (kg)

Mass/Volume (Density)

$1 \mathrm{lb} / \mathrm{ft}^{3}=16.02 \mathrm{kilogram} / \mathrm{meter}^{3}\left(\mathrm{~kg} / \mathrm{m}^{3}\right)$

\section{Temperature}

degree celsius $\left({ }^{\circ} \mathrm{C}\right)=5 / 9\left({ }^{\circ} \mathrm{F}-32\right)$

Mass/Time (Flow)

$1 \operatorname{perm}\left(73^{\circ} \mathrm{F}\right)=5.745 \times 10^{-11} \mathrm{kilogram} / \mathrm{pascal} \operatorname{second} \operatorname{meter}^{2}\left(\mathrm{~kg} / \mathrm{Pa} \cdot \mathrm{s} \cdot \mathrm{m}^{2}\right)$

Volume/Time (Flow)

$1 \mathrm{cfm}=0.000472$ meter $^{3} /$ second $\left(\mathrm{m}^{3} / \mathrm{s}\right)$

* Exactly 


\section{SI CONVERSION UNITS (Continued)}

Quantity of Heat

1 Btu $=1056$ joule $(\mathrm{J})$

Energy/Area Time

$1 \mathrm{Btu} / \mathrm{ft}^{2} \cdot \mathrm{h}=3.152$ watt $/$ meter $^{2}\left(\mathrm{~W} / \mathrm{m}^{2}\right)$

Thermal Resistance

$l^{\circ} \mathrm{F} \cdot \mathrm{h} \cdot \mathrm{ft}^{2} / \mathrm{Btu}=0.176 \mathrm{~meter}^{2} \mathrm{kelvin} /$ watt $\left(\mathrm{m}^{2} \cdot \mathrm{K} / \mathrm{W}\right)$ 
Table 1. Summary of Materials and Products and Cross-References to the

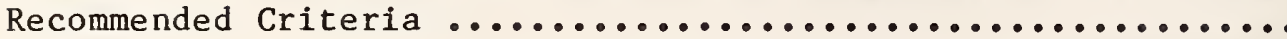

Table 2. Standards for Thermal Insulating Materials for Building Elements Including Walls, Floors, Ceilings, Attics, and

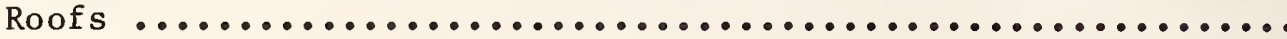

Table 3. Standards for Thermal Insulating Materials for Pipes, Ducts, and Equipment such as Boilers and Furnaces ...............

Table 4. Fire Safety Requirements for Thermal Insulating Materials

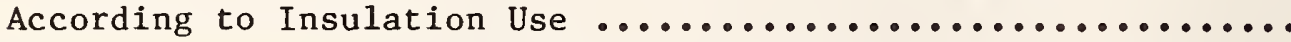

Table 5. Desirable Ranges of Total Thermal Resistances, $R_{t}$, of Walls, Roofs, Ceilings, and Floors for Ranges of Heating Degree-Days.

Table 6. Minimum Total Thermal Resistance of Insulation at Edges of Slabs-on-Ground Floors ...........................

Table 7. Standards Pertaining to Storm Windows .................

Table 8 . Standards Pertaining to Storm Doors .................. 23

Table 9. Standards for Replacement Windows ................... 26

Table 10. Standards for Replacement Doors ....................... 28

Table 11. Standards for Caulks and Sealants ................... 31

Table 12. Weatherstripping Criterion ...................... 34

Table 13. Standards for Vapor Retarders ....................... 35

Table 14. Standards for Clock Thermostats .................... 40

Table 15. Replacement Glazing Criterion .................... 41 
LIST OF FIGURES

Page

Figure 1. Condensation Zone Map .......................... 37 



\subsection{INTRODUCTION}

\subsection{BACKGROUND}

In the late 1970s, over one-third of the energy consumed in the United States was spent in heating, cooling, lighting, and other operations in residential and commercial buildings [1].* Many older homes, built before the 1973 oil embargo, at which time energy costs began to rise rapidly, were energy inefficient. When energy costs were low, many homes were constructed without adequate insulation in walls, ceilings, attics, and floors, without storm windows and doors, and without satisfactory caulking and weatherstripping. As fuel prices began to rise, it became apparent that significant reductions in residential heating and cooling costs could be accomplished by retrofitting homes to upgrade their thermal efficiencies [2, 3]. Over a decade ago, Seidel et al. [2] estimated that as much as 20 percent of the residential energy used in the United States could be saved through effective retrofitting. During the same time period, another study [4] indicated that more than 40 million single family residences should be considered for retrofitting. Recent estimates in 1980 indicate that approximately 28 million single-family residences were lacking one or more of the key energy conservation options [5]. Inspite of the conservation efforts carried out to date, many older homes are still energy inefficient and need to be upgraded. The term retrofitting, as used here, is the process whereby materials and products are added to existing homes in order to reduce the energy requirements for heating and cooling. The term, weatherization, is also applied to this process.

The savings in both dollars and energy from effective retrofitting of existing residences have been reported in the literature [1-4,6-21]. The reports cited show, in general, that a sound economic basis for retrofitting exists. It is beyond the scope of this study to present a review of the literature in this regard. Over the last decade many hundreds of papers have been published on retrofitting and energy conservation in buildings. By way of example, the proceedings of the conferences co-sponsored by the Department of Energy and ASTM** or ASHRAE*** may be cited [22-25] .

\subsection{WEATHERIZATION ASSISTANCE FOR LOW-INCOME PERSONS}

Weatherization of residences by the addition of insulation, storm windows and doors, and other measures is costly and may be beyond the financial capability of low-income persons. The United States Congress passed legislation directing the U.S. Department of Energy (DoE) to implement and manage a program of financial assistance to weatherize the homes of low-income families [26]. The program is intended to reduce national energy consumption and to reduce the impact of higher fuel costs on low-income familes. Low-income families,

* Figures in brackets indicate references listed in section 4.

** ASTM indicates American Society for Testing and Materials.

*** ASHRAE indicates American Society of Heating, Refrigerating and AirConditioning Engineers 
articularly the elderly and the handicapped, are more likely to live in poorly nsulated homes and, for example, in cold climates, may spend 30-40 percent of heir income on energy used for their homes [27]. Since 1977, this DoE program as weatherized about 1.2 million homes [27]. About 13 million households are resently eligible and it is currently estimated that the Weatherization Assistance 'rogram will save 20-25 percent of the energy expended by those assisted.

'he Weatherization Assistance Program restricts the type of materials, products, Ind equipment that can be installed and stipulates that these items must meet ipplicable criteria including standards. The major materials and products sriginally included in the scope of the program were insulations, storm windows and doors, caulks and sealants, weatherstripping, vapor retarders (barriers)*, and zlock thermostats. The primary intent of including these materials and products vas to aid low-income persons in reducing their heating-fuel consumption, while increasing their wintertime comfort. Nevertheless, some retrofit materials, for example, insulation, may be beneficial in both winter and summer.

The maximum allowable expenditure per residence for materials purchase, delivery, and other related costs is $\$ 1000$. This dollar figure may be increased to $\$ 1600$, if labor costs are required for installation of the materials and products. Incidental repairs to the residences, such as fixing broken windows or holes in the building envelope, are limited to $\$ 150$. The selection of materials and products, as well as the amount of material, to be applied to a given residence are determined according to energy audit procedures incorporated in the program [26].

In late 1983, DoE proposed changes to the Weatherization Assistance Program in order to increase flexibility in granting assistance to low-income families, while achieving the program's aims to conserve energy and to benefit low-income persons [28]. The revised rule for the Weatherization Assistance Program was finalized in early 1984 [29]. Changes in the program incorporated into the revised rule included: (1) the incorporation of new weatherization measures, (2) the updating of standards for materials and products for measures authorized in the program, and (3) adjusting the eligibility criteria for weatherizing certain multi-family and renter-occupied dwellings.

In support of the revision of the rule for the Weatherization Assistance Prograin, DoE requested the National Bureau of Standards (NBS) to review, revise, and update the criteria for eligibility of materials and products. In addition, it was requested that new criteria be recommended for weatherization measures not included in the scope of the original Weatherization Assistance Program, but considered suitable for inclusion in the revised program. These criteria may be used along with other information by DoE in the promulgation of standards for materials and products in the Weatherization Assistance Program. The report presents the results of the NBS study conducted as requested by DoE.

* Vapor retarders were generally in the past referred to as vapor barriers. 


\subsection{OBJECTIVES}

The objectives of this report are to revise and update the criteria for materials and products included in the DoE Weatherization Assistance Program; to recommend, as considered suitable, criteria for additional materials and products for inclusion in the Weatherization Assistance Program; to indicate areas of residences where the materials and products can be applied; and to point out precautions which should be followed in the installation of the retrofit materials and products. Although the criteria presented in the study were developed specifically for the Weatherization Assistance Program, it is believed that the information is valuable to anyone considering the retrofitting of a residence for energy conservation.

\subsection{SCOPE OF THE PROJECT}

In 1975, NBS published report NBSIR 75-795, "Recommended Criteria for Retrofit Materials and Products Eligible for Tax Credit [30]." Although this report was never used in support of Federal programs to grant tax credits to individuals who weatherized their homes, the recommendations in it provided, in large part, the basis of the criteria for materials and products included in the Weatherization Assistance Program [26]. That report recommended criteria for insulations, vapor retarders (barriers), storm windows and doors, caulks and sealants, weatherstripping, and clock thermostats.

In 1978, at the request of DoE, the criteria for these materials and products were reviewed by NBS. Recommendations on revisions were made in NBS Technical Note 982, "Criteria for Retrofit Materials and Products for Weatherization of Residences [31]." The materials and products for which criteria were given included those listed above (from the 1975 study), in addition to replacement windows and replacement glazing. In most cases, materials standards and specifications formed the basis for the criteria for the Weatherization Assistance Program.

In the present study, NBS Technical Note 982 was reviewed by NBS research staff in the Centers for Building Technology and for Fire Research to determine its current applicability to the Weatherization Assistance Program. The research staff included materials specialists, thermal and mechanical engineers, and fire safety engineers. The review indicated that Technical Note 982 would be applicable to the Weatherization Assistance Program, provided that some of the included information was updated and revised. In particular, voluntary consensus or industry standards cited in Technical Note 982 as the basis of criteria had in many cases been cancelled or reissued. Thus, it was decided that Technical Note 982 could provide a starting point to revise and update the existing criteria and to expand the criteria to include other materials and products. Recent versions of standards and specifications were reviewed for applicability to the criteria. They were complemented with technical information from the literature and discussions held with individuals knowledgeable in the thermal performance of buildings. 
The categories of materials and products for which criteria are recommended in this report for inclusion in the DoE Weatherization Assistance Program are insulation, storm windows and doors, replacement windows and doors, caulks and sealants, weatherstripping, vapor retarders (barriers), clock thermostats, and replacement glazing. They are, at times, referred to as architectural options or measures for weatherization [7], in contrast to mechanical options such as furnaces, boilers, and other equipment. Recommendations for criteria for mechanical options were outside the scope of this study. A parallel study to develop criteria for mechanical options is underway at NBS [32].

Criteria were recommended for the items listed above, since they are generally considered to be the basic retrofitting techniques which would be used to improve a residence which was in need of thermal upgrading. As demonstrated by Burch and Hunt [17] in a field study on the effectiveness of retrofit measures, the installation of insulation in walls, attics, and floors, the addition of storm windows and doors, and the reduction of air infiltration can significantly reduce the energy use of a residence. For example, in the Burch and Hunt study, a reduction in the heating energy requirements greater than 50 percent was achieved through the weatherization measures used. Most of the homes retrofitted under the DoE Weatherization Assistance Program are caulked and insulated, while some also have storm windows installed [27].

Other commercial materials and products are available for retrofitting. Examples are thermal insulations [33,34] for which consensus standards are not available, window accessories [16] including "movable insulation" items [35], and whole house fans [36].

\subsection{ORGANIZATION OF THIS REPORT}

Section 1 gives background information and the objectives and scope of the project.

Section 2 presents the recommended criteria for retrofit materials and products included in the DoE Weatherization Assistance Program.

Section 3 outlines precautions which should be taken during the installation of the retrofit items.

Section 4 lists references cited in this report.

Appendix A lists standards and specifications cited in this report. 


\subsection{RECOMMENDED CRITERIA FOR MATERIALS AND PRODUCTS INCLUDED IN THE DOE WEATHERIZATION ASSISTANCE PROGRAM}

The materials and products considered here for inclusion in the DoE Weatherization Assistance Program are insulation, storm windows and doors, replacement windows and doors, caulks and sealants, weatherstripping, vapor retarders, clock thermostats, and replacement glazing when used for retrofitting residences to save energy. This section gives criteria by which the eligibility of these materials and products is to be determined.

These criteria are based on factors such as thermal performance, fire safety, durability, quality, conformance to building codes, use, and ease of installation. FOR ALL ITEMS WHICH MEET THE CRITERIA, THEIR USE IS ONLY ALLOWED IF THE MATERIALS, PRODUCTS, AND INSTALLATION TECHNIQUES DO NOT VIOLATE APPLICABLE EXISTING LOCAL BUILDING-RELATED CODES. It is advisable to check with local code authorities if questions arise concerning whether a retrofit measure to be undertaken is acceptable under the local building-related codes.

Existing material standards and specifications were reviewed for their suitability as a basis for the criteria. For most individual items, conformance to existing specifications or standards is given as the criterion for the DoE Weatherization Assistance Program. For others, for example weatherstripping, for which there are no available applicable specifications or standards, but which provide important energy savings when retrofitted to existing housing, the recommended criterion is that the material or product be labeled, identifed or marketed as to its general category (e.g., weatherstripping) and properly installed. Regardless of the lack of standards or specifications for these items, they should be included in the DoE Weatherization Assistance Program, since they have been cited as effective for conserving energy in heating residences $[3,7-10,15,16,17]$.

The intent of the DoE Weatherization Assistance Program is to conserve energy through the encouragement of retrofitting. In cases where no applicable standards or specifications exist, but where adequate experience is available to confirm the effectiveness of the retrofit items, the use of these items should not be hindered by requiring that new standards or specifications be written. Also, the problem of enforcing conformance to the criteria in evaluating the validity of claims for inclusion in the DoE Weatherization Assistance Program was kept in mind. Complicated technical criteria could make enforcement difficult, if not practically impossible.

The materials and products considered eligible for inclusion in the DoE Weatherization Assistance Program are listed in table 1 along with a crossreference to the sections and tables of this report which contain the recommended criteria. All standards and specifications cited in this report are listed in Appendix A. These standards and specifications are periodically reviewed and, as a result, perhaps revised. Thus, the recommended criteria for the Weatherization Assistance Program should be reviewed from time to time to 
consider the latest revisions of the referenced standards and specifications. If determined to be applicable, the recommended criteria for the Weatherization Assistance Program should include the latest revisions of the referenced standards and specifications.

Table 1. Summary of Materials and Products and Cross-References to the Recommended Criteria

Material or Product Cross Reference

(1)

Insulation

Storm Windows

Storm Doors

Replacement Windows

Replacement Doors

Caulks and Sealants

Weatherstripping

Vapor Retarders

Clock Thermostats

Replacement Glazing
Section 2.1.3 (tables 2, 3, and 4)

Section 2.2.3 (table 7)

Section 2.3 .3 (table 8)

Section 2.4.3 (table 9)

Section 2.5.3 (table 10)

Section 2.6.3 (table 1l)

Section 2.7.3 (table 12)

Section 2.8.3 (table 13)

Section 2.9.3 (table 14)

Section 2.10.3 (table 15)

(1) Cross-reference refers to the sections of this report where the recommended criteria are given. 


\subsection{INSULATION}

2.1.1 Definition. Thermal insulation is a material or assembly of materials used primarily to provide resistance to heat flow.

2.1.2 Materials. The materials listed below are those considered suitable for use in residences to provide increased thermal resistance through retrofitting.

2.1.2.1 Types. Insulation is available in the following types [37]:

- Mineral fibrous materials such as glass, rock, or slag wool.

- Mineral cellular materials such as perlite and vermiculite.

o Organic fibrous materials such as wood, paper, or synthetic fibers.

- Organic cellular materials such as polystyrene or polyurethane.

- Composite materials whereby one or more layers of a mineral fiber, mineral cellular, or inorganic board insulation are laminated as a facing to an organic cellular insulation.

- Air spaces with either nonreflective, or metallic or metallized organic reflective surfaces.

2.1.2.2 Physical Forms. Insulation is available in the following physical forms [37]:

- Loose-fill. Loose-fill insulation consists of fibers, powders, granules, or nodules which are usually poured or blown into attics, walls, or other enclosed spaces.

- Flexible and Semirigid. These are materials with varying degrees of compressibility and flexibility, generally blanket, batt, or felt insulation. They are available in sheets or rolls of many types and varieties. Coverings and facings may be fastened to one or both sides to serve as reinforcing, vapor retarders, reflective surfaces, or surface finishes. Thickness and shape of insulation may be of any dimension conveniently handled, although standard sizes are generally used.

- Rigid. These materials are available in rectangular dimensions called block, board, or sheet, and preformed during manufacture to standard lengths, widths, and thicknesses.

o Foamed-in-Place. These materials are available as liquid components which may be poured, frothed, or sprayed in place to form rigid or semirigid foam insulation.

2.1.3 Criterion. Materials used for thermal insulation should meet requirements for heat flow resistance, fire safety, and quality. ASTM Standards, and in a few instances, Federal Specifications (F.S.), are available which state requirements for heat flow resistance and quality of the insulations, but which are in some cases incomplete with regard to fire safety. Retrofitting residences by the addition of thermal insulation should be accomplished in such a manner so as not to decrease the overall fire safety of the residence. This depends to a large extent on where the insulation is used and how it is installed. 
Table 2 lists thermal insulating materials for building elements including walls, floors, ceiling, attics, and roofs. Thermal insulating materials for pipes, ducts, and equipment such as boilers and furnaces are given in table 3. In general, materials conforming to the ASTM Standards and Federal Specifications listed in these tables are considered to meet the requirements for heat flow resistance and quality. As previously indicated, these standards and specifications may not include adequate fire safety requirements. As such, the insulation materials listed in tables 2 and 3 should be acceptable for the Weatherization Assistance Program only if they:

(a) conform to the applicable fire safety requirements presented in section 2.1 .3 .1 and listed in table 4 ,

(b) conform to the requirements other than fire safety of the applicable ASTM Standards and Federal Specifications given in tables 2 and 3 , and

(c) are properly installed as designated in section 2.1 .4 .

Each insulation should be labeled as conforming to the applicable standards, specifications, fire safety requirements, and areas of application.

2.1.3.1 Fire Safety Requirements for Thermal Insulation Materials. Some ASTM Standards and Federal Specifications currently require that the fire performance of the various insulation materials be evaluated according to the test procedures described in ASTM E 84, "Surface Burning Characteristics of Building Materials." Additional or different fire safety requirements are deemed necessary according to how the insulation is used, e.g., within an enclosed stud or joist space, exposed on the floor of an attic, or exposed on a wall or ceiling.

\section{1 .3 .1 .1 Attic Floors}

- Critical Radiant Flux. Critical radiant flux is the level of incident radiant heat energy on the attic floor insulation system below which flame propagation ceases under prescribed test conditions. For insulations, the critical radiant flux should be equal to or greater than $1.2 \mathrm{~kW} / \mathrm{m}^{2}$.

The critical radiant flux is determined by the test procedure described in ASTM E 970 ( 16 CFR $^{*}$ Part 1209). This method of test provides a basis for evaluating the surface flame spread behavior of an attic floor insulation in a building attic, since "critical radiant flux" is a meaningful measure of the sensitivity to flame spread of installed attic floor insulation. 
Table 2. Standards for Thermal Insulating Materials for Bullding Elements Including Walls, Floors, Ceilings, Attics, and Roofs

Material or Product

Criteria for Eligibility(1) conformance to:

Insulation - mineral fiber

o blanket

ASTM C $665-78$

o roof insulation

ASTM C 726-81

o loose - fill

ASTM C 764-73(1979)

Insulation - mineral cellular

o vermiculite loose - fill

ASTM C $516-80$

o perlite loose - fill

ASTM C 549-81

- cellular glass block

ASTM C 552-79

- perlite board

ASTM C $728-82$

Insulation - organic fiber

- cellulosic fiber board

ASTM C 208-72(1982)

- cellulose loose - fill

Interim Safety Standard

16 CFR Part 1209

Insulation - organic cellular

- preformed polystyrene

ASTM C 578-83

- unfaced preformed rigid polyurethane

ASTM C 591-83

- polyurethane or polyisocyanurate

F.S. HH-I $-1972 / 1$

board faced with aluminum foil

- polyurethane or polyisocyanurate

F.S. HH-I-1972/2

board faced with felts

Insulation - composite boards

- mineral fiber and rigid cellular

polyurethane composite board

ASTM C 726-81

- perlite and rigid cellular

ASTM C 984-83

polyurethane composite board

- gypsum board and polyurethane

F.S. HH-I-1972/4

or polyisocyanurate composite board

(1) Criteria for eligibility for thermal insulating materials include fire safety requirements which are dependent upon the use of the insulation. Fire safety requirements are given in table 4 and section 2.1.3.1. 
Table 3. Standards for Thermal Insulating Materials for Pipes, Ducts, and Equipment such as Boilers and Furnances

Materials or Product
Insulation - mineral fiber

- preformed pipe

- blanket and felt (industrial type)

- blanket insulation and blanket type pipe insulation (metal-mesh covered) (industrial type)

- block and board

- spray-applied fibrous for elevated temperature

- high temperature fiber blanket

- duct work

Insulation - mineral cellular

- diatomaceous earth block and pipe

- calcium silicate block and pipe

- cellular glass block and pipe

- expanded perlite block and pipe

Insulation - organic cellular

- preformed flexible elastomeric cellular in sheet and tubular form

- rigid preformed cellular urethane
Criteria for Eligibility(1) conformance to:

ASTM C 547-77

ASTM C 553-70(1977)

ASTM C $592-80$

ASTM C 612-77

ASTM C 720-72(1979)

ASTM C $892-78$

ASTM C $971-82$

ASTM C 517-71(1979)

ASTM C 533-80

ASTM C 552-79

ASTM C 610-67(1974)

ASTM C $534-82$

ASTM C 591-69

(1) Criteria for eligibility for thermal insulating materials include fire safety requirements which are dependent upon the use of the insulation. Fire safety requirements are given in table 4 and section 2.1.3.1. 
Table 4. Fire Safety Requirements for Thermal Insulating Materials According to Insulation Use

Insulation Use

Attic Floor

Enclosed Spaces
Fire Safety Requirement

Insulation materials intended for exposed use in attic floors should be capable of meeting the same flammability requirements for cellulose insulation in 16 CFR Part 1209.

Insulation materials intended for use within enclosed stud or joist spaces should be capable of meeting the smoldering combustion requirements for cellulose insulation in 16 CFR Part 1209.

Insulation materials, including those with combustible facings, which remain exposed and serve as wall or ceiling interior finish should have a flame spread classification not to exceed 150 (per ASTM E 84).

Organic cellular insulations (plastic foams) are not permitted to remain exposed in habitable or occupiable areas. Building codes require organic cellular insulations to have a maximum flame spread classification of 75 and to be protected by a layer of gypsum board of $1 / 2$ inch thickness or greater, or an equivalent fire barrier.

Exterior envelope walls and roofs containing thermal insulations should meet applicable building code requirements for the complete wall or roof assembly.

Insulation materials intended for use on pipes, ducts, and equipment should be capable of meeting a flame spread classification not to exceed 150 (per ASTM E 84). 
Smoldering Combustion. This test determines the tendency of the insulation to support and propagate smoldering combustion subsequent to exposure to a standard localized ignition source.

When tested for smoldering combustion, the insulation should meet the following requirements:

a) weight loss should not exceed 15 percent of the initial mass, and b) no evidence of flaming combustion should be observed.

The smoldering combustion test is conducted according to the procedure described in 16 CFR Part 1209.

- Flame Resistance Permanency. Thermal insulations having chemical retardants should retain their flame resistance throughout their service lifetime. At the present time it is considered that an adequate test procedure is not available for assessing this property of insulations.

\subsection{Enclosed Spaces}

- Smoldering Combustion. Insulations installed in enclosed spaces should meet the smoldering combustion requirements summarized in section $2 \cdot 1 \cdot 3 \cdot 1 \cdot 1$.

- Surface Burning Characteristics. The flame spread classification of organic cellular (plastic foam) insulation should not exceed $75 .^{*}$

The ASTM E 84 flame spread test method is the basis for evaluating the surface burning characteristics of organic cellular insulations when used in enclosed spaces.

\subsection{Exposed Interior Walls and Ceilings}

- Surface Burning Characteristics. The flame spread classification index of blankets, boards, and other types of insulations used in exposed locations on walls and ceilings should not exceed 150 .

* Organic cellular insulations are difficult to evaluate using ASTM E 84 . The requirement of a flame spread classification of 75 maximum for these foams, in conjunction with a smoldering combustion test, is intended to provide reasonable limits on ignitiability and flammability using currently available standard test methods. A flame spread classification of 75 (or any other numerical classification) shall not be construed as the equivalent of "noncombustible". 
The ASTM E 84 flame spread test method is the basis for evaluating the surface burning characteristics of insulation materials used in exposed locations on walls and ceilings. Where blankets or boards with facings are to be used exposed in rooms, attics, crawl spaces, garages, and other locations, the surface burning characteristics of the membrane-faced insulation should be measured.

2.1.3.1.4 Exterior Envelope Walls and Roofs. Insulation materials contained within the exterior wall or roof construction should meet applicable building code requirements. For example, ASTM E 108 is the standard test method used to measure and prescribe the fire performance of roof coverings intended for installation on combustible or noncombustible decks. This test measures the ability of the roof covering material (including insulation) to prevent the formation of flying brands and to resist surface spread of flame and fire penetration from the exterior.

2.1.3.1.5 Pipes, Ducts, and Equipment. Insulation materials intended for use on pipes, ducts, and mechanical equipment should be capable of meeting a flame spread classification not to exceed 150 (per ASTM E 84).

2.1.4 Areas of Application. Materials used for thermal insulation may be applied in residences as outlined in tables 2 and 3 to the following areas: walls, roofs, attics, ceilings, floors, foundations, pipes, ducts, hot water heaters, vessels, and equipment.

2.1.4.1 Organic Cellular Insulations. Organic cellular insulations (non-faced or faced, untreated or fire-retardant treated) should not be permitted to remain exposed in habitable or occupiable areas. These materials should be protected by a layer of gypsum board of $1 / 2$ inch thickness or greater, or an equivalent fire barrier.

2.1.4.2 Electrical Services. Installation of thermal insulation around electrical service components may reduce the ability of such components to dissipate harmlessly heat generated during their operation. In addition, installation of thermal insulation adjacent to power service entry and distribution boxes may hinder heat release and thus influence normal operation of overcurrent protection devices (fuses and circuit breakers). Trechsel and Launey [38] indicated that there are three electrical service components that are of primary importance as related to the possibility of excessive temperatures due to the installation of thermal insulation in walls and ceilings: wires and fuses, recessed lighting fixtures, and surface-mounted lighting fixtures. To prevent hazards due to the installation of thermal insulation, they suggested a number of precautions, many of which are repeated in the following sections (2.1.4.2.1 through 2.1.4.2.4) for the Weatherization Assistance Program.

2.1.4.2.1 Wiring and Fuses. Prior to installing thermal insulation so as to surround or encapsulate electrical wiring: 
o Conventional (Edison-base) fuses should be replaced with S-type fuse adaptors (S-type fuse adaptors only accept correct loadampere rated fuses);

o Oversized circuit breakers for branch circuits should be replaced with correctly rated ones;

- In houses in which signs of beginning failure in electrical systems are apparent, an inspection should be performed prior to the installation of thermal insulation by either a licensed electrician or the local power company; and

- "Code rubber" wiring (generally found in houses built prior to 1940) should be inspected to determine its condition by an approved electrician prior to the installation of thermal insulation which will encapsulate the wiring.

2.1.4.2.2 Recessed Lighting Fixtures. The National Electrical Code (NFPA 701981) states that "thermal insulation shall not be installed within 3 inches of the recessed fixture enclosures, wiring compartment, or ballast and shall not be so installed above the fixture as to entrap heat and prevent the free circulation of air unless the fixture is otherwise identified for installation with thermal insulation."

2.1.4.2.3 Surface-Mounted Lighting Fixtures. Prior to the installation of insulation above ceiling-mounted fixtures, the following precautions should be taken for fixtures not specifically approved for installation under insulated ceilings:

- Assure that the light bulbs used in the fixture are of no greater wattage than the fixture was designed for. For example, a fixture designed to carry two 60-watt bulbs should never carry two 100watt bulbs (or one 60 and one 100-watt bulb). If the fixture does not carry a marking stating the maximum allowable wattage (or a recommended wattage), assume that 60 watts per bulb is the maximum allowable.

2.1.4.2.4 Insulation in Electrical Boxes. After the installation of loosefill insulation, electrical boxes need to be inspected and any insulation that has lodged in the boxes must be cleaned out. Prior to this inspection and cleaning-out operation, electrical current in the particular circuit must be shut off.

2.1.5 Commentary. Although a degree of material combustibility is allowed, the intent of the fire safety requirements is to allow insulating materials which are not more combustible (or flammable) than acceptable existing construction and insulation materials, and to preclude any increased fire hazard due to the retention of heat from energy-dissipating objects. 
In areas where occupants are likely to be engaged in normal activities, the insulation should perform its intended function without the increased risk of ignition, rapid flame spread, and heat and smoke generation. Insulation in concealed spaces may be a particular fire problem due to its susceptibility to smoldering and its inaccessibility for fire fighting.

Although the primary fire safety properties of insulation relate to ignitability and heat release, at the present time suitable standard test methods and standard application practices using test results do not exist for evaluating these properties. It is recommended that the critical radiant flux, smoldering combustion, and flame spread classification test methods be used to judge fire performance.

The organic cellular insulation industry recommends that cellular plastic insulation used in all interior and/or ceiling construction, unless specifically approved on the basis of specialized tests, should be covered with at least $1 / 2$ inch of cement plaster or fire-rated gypsum wallboard or an equivalent barrier providing a finish fire rating of 15 minutes or more. This recommendation has been incorporated in building codes and federal regulations for all organic cellular insulations for various types of buildings.

It is mandatory that cellulose insulation conforms to the requirements of the Consumer Product Safety Commission, "Interim Safety Standard for Cellulose Insulation" (16 CFR Part 1209). This Interim Safety Standard supersedes by law voluntary consensus and other standards which may be available in the United States.

Proper retrofitting requires the installation of adequate amounts of insulation to reach desirable levels of heat flow resistance. Because heating and cooling costs vary with energy prices, the amount of insulation that is economically justified based on energy costs increases with the price of fuel [3]. For the various geographical locations as designated by heating degree-days, the total thermal resistance, $R_{t}$, resulting from retrofitting thermal insulation to opaque portions of walls, roofs, ceilings, and floors should lie within the ranges of values given in table 5. It may not always be possible to insulate to the levels suggested in table 5 because of practical considerations concerning the building construction. For example, wall cavities in wood-frame construction are normally no deeper than 4 inches. The retrofitting of insulation at the edges of slab floors to reduce slab edge heat loss should give resultant thermal resistance, $\mathrm{R}-\mathrm{v}$ alues, and total depths of insulation at the slab edges as listed in table 6 .

Air ducts, plenums, pipes, and other surfaces installed in unheated spaces (e.g., attics, unheated garages, crawl spaces, etc.) should be thermally insulated to provide an inside surface to outside surface thermal resistance of not less than $\mathrm{R}=\Delta \mathrm{T} / 8$, where $\Delta \mathrm{T}$ is the maximum temperature difference $\left({ }^{\circ} \mathrm{F}\right.$ ) between the duct (or other enclosure) and the surrounding air, or should be insulated to a value of $R=5$, whichever is greater. Air 
leaks in ducts and plenums can be a significant source of energy loss. Thus, such air leaks should be sealed before ducts and plenums are thermally insulated.

The thermal resistance of building and insulating materials and components may be obtained or calculated from values given in table 3 of chapter 23 of the ASHRAE Handbook of Fundamentals [37]. The procedure for calculation of total thermal resistance, $R_{t}$, is given in this Handbook. Table 4 of chapter 23 of the ASHRAE Handbook of Fundamentals [37] gives examples for computation of total thermal resistance. 
Table 5. Desirable Ranges of Total Thermal Resistances, $R_{t}{ }^{(1)}$, of Walls Roofs, Ceilings, and Floors, for Ranges of Heating Degree-Days (2)
Heating Degree-Days $(3)$
$0-4500$
$4501-8000$
8001 or more

Flat roof deck

$12-20$

$20-30$

$20-40$

Ceilings

$20-30$

$30-40$

$40-50$

Masonry wall construction

$4-11$

$10-12$

$11-17$

Frame wall construction

$12-15$

$12-20$

$12-25$

Floors (4)

$1-11$

$12-20$

$20-25$

(1) Values of total thermal resistance are given in units ${ }^{\circ} \mathrm{F} \cdot \mathrm{h} \cdot \mathrm{ft} \mathrm{t}^{2} / \mathrm{Btu}$. To obtain transmittance, $U=1 / R_{t}$.

(2) In retrofitting many residences, it may not be possible to upgrade the total thermal resistance of a wall, roof, ceiling, or floor to the greatest desirable value for a given degree-day range because of practical limitations concerning the building construction. Thus, there is overlap in some of the ranges of total thermal resistance for the ranges of heating degree-days.

(3) Values of degree-days for many geographical locations are given in chapter 43 of the ASHRAE Systems Handbook [39].

(4) Total resistance values for floors over basements, unheated garages, or crawl spaces with no positive heat supply.

Table 6. Minimum Total Thermal Resistance of Insulation at Edge of Slabs-on-Ground Floors

\begin{tabular}{ccc}
\hline Heating Degree-Days & $\begin{array}{c}\text { Thermal Resistance, } R \\
{ }^{\circ} \cdot \mathrm{h} \cdot \mathrm{ft}^{2} / \mathrm{Btu}\end{array}$ & $\begin{array}{c}\text { Depth of Insulation } \\
\text { inches }\end{array}$ \\
\hline $2500-4500$ & 4.0 & 18 \\
$4501-8000$ & 5.0 & 24 \\
8001 or more & 7.0 & 24 \\
\hline
\end{tabular}




\subsection{STORM WINDOWS}

2.2.1 Definition. A storm window is an extra window, normally installed to the exterior of the prime window to increase resistance to heat flow and to decrease air infiltration. Less commonly, storm windows are installed on the interior of the prime windows. Storm windows may be removable or permanently attached, operable, or fixed. Two general types of storm windows may be described. In one case, the storm window is part of a combination unit having screens. A mounting frame which contains tracks for the windows and screens is attached to the prime window assembly. The windows and screens in these units are usually removable and/or operable. In the second case, the storm window frame is mounted directly to the prime window assembly, and the storm window may be operable or inoperable depending upon the method of mounting.

2.2.2 Materials. Storm windows may be constructed of aluminum, wood, or rigid vinyl [poly(vinyl chloride)] frames with glass or plastic glazing. Flexible and rigid plastic sheeting may also be used.

2.2.3 Criterion. Storm windows for retrofitting should conform to the standards or special provisions listed below and given in table 7 , and be installed as stated in Section 2.2.4. Each storm window should be labeled as conforming to the applicable standard or special provision.

2.2.3.1 Aluminum Combination Units and Frame Storm Windows. Aluminum combination storm window units should conform to the American National Standard Institute ANSI/AAMA 1002.10-83, "Voluntary Specifications for Aluminum Insulating Storm Products for Windows and Sliding Glass Doors." Aluminum frame storm windows should conform to Sections $1.2,1.3,1.4$, and 1.6 of ANSI/AAMA $1002.10-83$.

2.2.3.2 Wood Frame Storm Windows. Wood frame storm windows should conform to Section 3 of the American National Standard Institute ANSI/NWMA I.S. 2-80, "Wood Windows."

2.2.3.3 Rigid Vinyl Frame Storm Windows. Rigid vinyl frame storm windows should conform to Section 6.1 through $6.7,6.12$, and 6.13 of ASTM D 4099-82, "Standard Specification for Poly(Vinyl Chloride) (PVC) Prime Windows."

2.2.3.4 Frameless Plastic Glazing. Plastic glazing used as frameless storm windows should consist of either rigid or flexible sheets, a minimum of $6 \mathrm{mil}(0.006 \mathrm{in})$ thick.

2.2.4 Areas of Application. Storm windows used for retrofitting may be installed on residences to existing prime windows. Installations should not violate any applicable existing local building-related code. A minimum of 1/2-inch of air space should be provided between the glazing of the prime and storm windows. 
Table 7. Standards Pertaining to Storm Windows

Material or Product

Criteria for Eligibility

conformance to:

\section{Storm Windows}

o Aluminum combination unit ..........ANSI/AAMA (1) 1002.10-83

- Aluminum frame ................ Sections 1.2, 1.3, 1.4, and 1.6 of ANSI/AAMA $1002 \cdot 10-83$

o Wood frame .................................. 3 of ANSI/NWMA (2)

I.S.2-80

- Rigid vinyl frame .............. Sections 6.1 through 6.7, 6.12, and 6.13 of ASTM D 4099-82

- Frameless plastic glazing required minimum thickness, 6 mil $(0.006$ in)

(1) ANSI/AAMA indicates American National Standards Institute/Architectural Aluminum Manufacturers Association

(2) ANSI/NWMA indicates American National Standards Institute/National Woodwork Manufacturers Association 
2.2.5 Commentary. Some storm windows are installed in a fixed position and cannot be opened. This may create a ventilation problem. Also, fixed position storm windows may hinder or prevent egress in case of emergency. When installing any type of storm window, the installed storm window should not restrict the existing capacity and access required for occupant egress via windows. It is normally expected that one (or more) bedroom and living room windows can serve as emergency means of exit and will be easily openable and of suitable dimensions and area ( $5 \mathrm{ft}^{2}$ ). Local building-related codes should be consulted for regulations regarding retrofitting with storm windows, particularly those installed in a fixed position.

Installation of storm windows may cause moisture build-up between the outer and inner windows. This moisture build-up may be reduced or eliminated by the use of small ventilation openings (generally called weep holes) in the outer window sash. In general, exterior storm windows should be less airtight than prime windows, and interior storm windows should be tighter than prime windows.

Storm windows may not alway provide a decrease in air infiltration. The reduction in air infiltration depends upon the relative tightness of the original prime window and the storm window.

2.2.5.1 Aluminum Combination Units and Frame Storm Windows. The intent of the criterion is to assure the quality of storm windows which are used for energy conservation. Section 1.7 of ANSI/AAMA 1002.10-83 gives an option for certification of a storm window to show compliance with the standard. It is not the intent to require certification to the standard; however, labeling that the storm windows meet the provisions of the standard is recommended.

2.2.5.2 Wood Frame Storm Windows. ANSI/NWMA I.S. 2-80 was not developed for storm windows, but rather for prime windows. Section 3 of the standard is used as the criterion in retrofitting to assure the quality of the materials and the quality of the construction of the windows.

2.2.5.3 Rigid Vinyl Frame Storm Windows. ASTM D 4099-82 was not developed for storm windows, but rather for prime windows. Sections 6.1 through $6.7,6.12$, and 6.13 of this standard are used as the criterion to assure the quality of the materials and construction of this type of window.

2.2.5.4 Frameless Plastic Glazing. Flexible and rigid plastic sheeting can be effective in reducing heat flow and are acceptable for use as storm windows. Flexible sheeting offers an economical method for retrofitting but has a short life, perhaps lasting only one season.

In the installation of frameless plastic glazing, consideration should be given to the fact that interior installation is easier and provides greater protection to the plastic. In this case, condensation on the interior of the prime window may appear and may be difficult to remove. 
To reduce the possibility of condensation, the plastic glazing installed on the interior should be sealed continuously along its perimeter and not contain weep holes. In addition, the plastic glazing should have a low water vapor permeability.

Outside installation is more difficult (e.g., 2 story houses) and damage to the plastic is more likely from the elements. Flexible sheeting installed outside may pose a noise problem due to fluttering caused by wind. In the case of outside installation, condensation which occurs on the plastic glazing may in general be removed from the inside by opening the prime window and wiping with a towel or other means. As mentioned previously, condensation may be reduced or prevented if the exterior plastic glazing is not installed airtight, and limited air infiltration is permitted.

In recent years, frameless plastic glazing kits for storm window applications have become available. These kits normally consist of a plastic flexible sheet or film (the glazing) and accessory items for attaching the glazing on the interior side of the prime window. The attachment device or mechanism is intended to provide a tight seal between the storm window and the prime window. The thickness of the glazing in some of these kits may be less than 6 mils $(0.006$ in.), which is the minimum thickness recommended in this report as the criterion for frameless plastic glazing. Nevertheless, attention may be given to using these types of storm windows for interior use in cases where they might be considered appropriate.

\subsection{STORM DOORS}

2.3.1 Definition. A storm door is an extra door, installed to the outside or inside of an exterior prime door, to provide greater resistance to heat flow and to reduce air infiltration. Both hinged and sliding type doors are available.

2.3.2 Materials. Storm doors may be constructed of aluminum, wood, or rigid vinyl frames with glazing, or of wood without glazing.

2.3.3 Criterion. Storm doors installed for retrofitting should conform to the standards listed below and given in table 8, and be installed as stated in Section 2.3.4. Whenever storm doors contain glazing, safety glazing is required in conformance to 16 CFR Part 1201, "Safety Standard for Architectural Glazing Materials." Storm doors should be labeled as conforming to the applicable standard, as well as the Safety Standard for glazing whenever the storm doors contain glazing.

2.3.3.1 Aluminum Frame Storm Doors and Sliding Glass Storm Doors.

- Aluminum frame storm doors should conform to ANSI/AAMA 1102.71977, "Voluntary Specifications for Aluminum Storm Doors." 
Table 8. Standards Pertaining to Storm Doors

Material or Product

Criteria for Eligibility (1)

conformance to:

\section{Storm Doors}

- Aluminum

- Frame ............................ANSI/AAMA 1102.7-1977

- sliding ...............................

- Wood

- Pine ......................................... 5-83

- Fir, hemlock, spruce ............... Section 3 of FHDA(2)/7-79

○ Rigid Vinyl ................................. D 3678-81

(1) Whenever storm door contains glazing, safety glazing is required in conformance to 16 CFR Part 1201, "Safety Standard for Architectural Glazing Materials."

(2) FHDA indicates Fir and Hemlock Door Association 
- Sliding glass storm doors should conform to ANSI/AAMA 1002.10-83, "Voluntary Specifications for Aluminum Insulating Storm Products for Windows and Sliding Glass Doors."

\subsubsection{Wood Storm Doors With and Without Glazing}

- Pine storm doors should conform to the requirements of exterior doors listed in Section 3 of ANSI/NWMA I.S. 5-83, "Ponderosa Pine Doors."

- Fir, hemlock, and spruce storm doors should conform to the requirements for exterior doors listed in Section 3 of the Fir and Hemlock Door Association Industry Standard FHDA/7-79, "Industry Standard for Douglas Fir, Western Hemlock, and Sitka Spruce Doors."

2.3.3.3 Rigid Vinyl Frame Storm Doors. Rigid vinyl frame storm doors should be constructed with vinyl profile extrusions which conform to ASTM D 3678-81, "Standard Specification for Rigid Poly(Vinyl Chloride) (PVC) Interior-Profile Extrusions."

2.3.4 Areas of Application. Storm doors used for retrofitting may be installed on residences to any existing prime exterior door. Installation should not violate any applicable existing local building-related code.

2.3.5 Commentary. The addition of storm doors should not endanger the safety of the occupants of the dwelling. Doors are the normal means of exit from a residence, and an installed storm door should not make it more difficult for persons to exit.

To reduce the risk of bodily injury due to accidental impact with storm doors containing glazing, safety glazing should be used whenever storm doors contain glazing. The Consumer Product Safety Commission, "Safety Standard for Architectural Glazing Materials" (16 CFR Part 1201), requires that safety glazing be used in storm doors. The requirements of this Safety Standard are mandatory and supersede local and national code requirements which do not meet or exceed those in the Safety Standard.

The economic feasibility of installing storm doors should be carefully considered. In his study on the economic benefits of installing retrofit materials and products, Petersen [3] found that the addition of storm doors was in many cases not cost-effective, assuming that a screen door was being replaced. Storm doors were cost-effective in areas of high fuel costs and severe climates. 
2.3.5.1 Aluminum Frame Storm Doors and Sliding Glass Storm Doors. The intent of the criteria is to assure the quality of the storm doors necessary for satisfactory performance and that energy savings will be realized through their use. Section C 1.10 of ANSI/AAMA 1102.7-1977 and Section 1.7 of ANSI/AAMA 1002.10-83 give an option for certification of a storm door to show compliance with the applicable standard. It is not the intent to require certification to the applicable standard; however, labeling that the storm doors meet the provisions of the applicable standard is recommended.

2.3.5.2 Wood Frame or Wood Storm Doors. The standards AlISI/NWMA I.S. 5-83 and FHDA/7-79 were not developed for storm doors, but rather for prime wooden doors. Section 3 of each standard is used for criteria in retrofitting because there are no existing performance standards or specifications that have been developed specifically for wooden storm doors. Conformance to the requirements given in section 3 of each standard helps to assure the quality of the materials and construction of the storm doors.

If woods other than those listed in Section 2.3.3.2 are used to construct storm doors, the quality of these doors shall be equal to the quality of the doors listed in Section 2.3.3.2.

2.3.5.3 Vinyl Frame Storm Doors. ASTM D 3678-81 is concerned with the quality of vinyl-profile extrusions, and not completed doors. There are no existing performance standards or specifications that have been developed specifically for vinyl frame storm doors.

ASTM D 3678-81 has been developed for poly(vinyl chloride) interiorprofile extrusions. Nevertheless, it is noted that vinyl frame prime windows specified in ASTM D 4099-82 have interior-profile extrusions that conform to ASTM D 3678-81.

\subsection{REPLACEMENT WINDOWS}

2.4.1 Definition. For purposes of retrofitting, a replacement window is a thermally improved prime window including the frame, sash, and glazing. It is installed in a residence after removal of the existing window and frame assembly to increase resistance to heat flow and to decrease air infiltration.

2.4.2 Materials. Replacement window frames and sashes may be constructed of aluminum, steel, wood, or vinyl with glass or plastic glazing.

2.4.3 Criterion. Replacement windows for retrofitting should conform to the standards listed below and in table 9 , and be installed as stated in Section 2.4.4. In addition, replacement windows should have multiple glazing, and metal frames should contain a thermal break to reduce heat flow. In the case of multiple glazing, sealed insulating glass units are preferred and they should conform to ASTM E 774-81, "Standard Specifications for Sealed Insulating Glass Units." 
2.4.3.1 Aluminum Frame Replacement Windows. Aluminum frame replacement windows should conform to ANSI/AAMA 302.9-1977, "Voluntary Specifications for Aluminum Prime Windows."

2.4.3.2 Steel Frame Replacement Windows. Steel frame replacement windows should conform to, "Steel Window Specifications," Steel Window Institute, 1983.

2.4.3.3 Wood Frame Replacement Windows. Wood frame replacement windows should conform to ANSI/NWMA I.S. 2-80, "Wood Windows."

2.4.3.4 Vinyl Frame Replacement Windows. Vinyl frame replacement windows should conform to ASTM D 4099-82, "Standard Specification for Poly(Vinyl Chloride) (PVC) Prime Windows."

2.4.4 Areas of Application. When warranted because of excessive air infiltration, any residential prime window and frame assembly may be replaced. Installation should not violate any applicable existing local building-related code.

2.4.5 Commentary. Any warping, poor fitting, or damage that could not be overcome by weatherstripping of a prime window would suggest a need for its replacement. Installation of weatherstripping and storm windows are alternative methods to reduce heat flow and air infiltration through windows. In cases where it is not possible to install storm windows to prime windows, replacement windows may be warranted. As compared to storm windows, the potential of replacement windows to reduce energy consumption is related to the decrease in air infiltration which is achieved through the replacement of windows, as well as the improved thermal resistance which it provides.

Thermally improved windows incur low rates of heat flow and air filtration. Multiple glazing and thermal breaks in metal window frames are intended to provide low rates of heat flow and therefore increased benefits for energy conservation. Although sealed insulating glass units are preferred for multiple glazing, the cost of these units may preclude their use in the Weatherization Assistance Program. The ASHRAE Standard 90-80, "Energy Conservation in New Building Design," recommends that the air infiltration through windows not exceed $0.5 \mathrm{cfm}$ per linear foot of sash crack length. The standards referenced in Sections 2.4.3.1 through 2.4.3.4 contain requirements for maximum allowable air infiltration which agree with this ASHRAE Standard.

Replacement window frames should be properly caulked and sealed into the wall of the residence to prevent air infiltration at these locations. Replacement windows should be labeled as manufactured to conform to the applicable criteria given in Section 2.4.3. It is not required that they be certified by independent laboratories as meeting these provisions. However, test results may be needed to assure conformance to the applicable criteria. 
Table 9. Standards for Replacement Windows

Material or Product

Criteria for Eligibility(1)

conformance to:

Replacement Windows

- Aluminum frame

ANSI / AAMA 302.9-1977

o Steel frame SWI(2) Specifications for Steel Windows, 1983

$\circ$

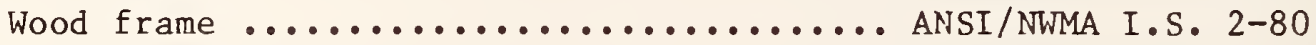

o Rigid vinyl frame ........................ D 4099-82

(1) Replacement windows should have multiple glazing and metal frames should contain a thermal break to reduce heat flow. Sealed insulating glass units are preferred and should conform to ASTM E 774-81, "Standard Specifications for Sealed Insulating Glass Units."

(2) SWI indicates Steel Window Institute.

\subsection{REPLACEMENT DOORS}

2.5.1 Definition. For purposes of retrofitting, a replacement door is a thermally improved exterior prime door. It is installed in a residence after removal of an existing door to increase resistance to heat flow and decrease air infiltration. Such doors may be classified as either hinged or sliding patio doors. Replacement of a hinged door may or may not require replacement of the frame, whereas replacement of a sliding patio door normally requires replacement of the frame.

2.5.2 Materials. Replacement doors may be constructed of wood or metal with or without glazing, or of metal or wood exterior skin with an insulated core. Metal doors are either aluminum or steel and insulated doors may contain glazing.

2.5.3 Criterion. Replacement doors for retrofitting should conform to the standards and special provisions listed below and in table 10, and should be installed as stated in section 2.5.4. Where glazing is used it should conform to the requirements of 16 CFR Part 1201 , "Safety Standard for 
Architectural Glazing Materials." If sealed insulating glass units are used, they should conform to ASTM E 774-81, "Standard Specifications for Sealed Insulating Glass Units." These doors should be labeled as being manufactured to conform to the criterion.

2.5.3.1 Hinged (Swinging) Doors. The coefficient of thermal transmittance (U-value) for replacement hinged (swinging) doors should not be greater than $0.45 \mathrm{Btu} / \mathrm{h} \cdot \mathrm{ft}^{2}{ }^{\circ} \mathrm{F}$ as determined by the method for calculating overall coefficients of heat transmission given in Chapter 23 in the ASHRAE Handbook of Fundamentals [37]. In addition, replacement hinged doors should conform to the applicable specification as follows:

- Steel replacement doors should conform to Steel Door Institute Recommended Specifications S.D.I. 100-83, "Standard Steel Doors and Frames."

- Pine replacement doors should conform to the provisions for exterior doors listed in ANSI/NWMA I.S. 5-83, "Ponderosa Pine Doors."

- Fir, hemlock, and spruce replacement doors should conform to the provisions for exterior doors listed in the Fir and Hemlock Door Association Standard FHDA/7-79, "Industry Standard for Douglas Fire, Western Hemlock, and Sitka Spruce Doors."

- Wood flush doors should conform to the provisions for exterior doors listed in ANSI/NWMA 1-80 Series, "Wood Flush Doors."

2.5.3.2 Sliding Patio Doors. Sliding patio doors should have multiple glazing (preferably sealed insulating glass units) and metal frames should contain a thermal break to reduce heat flow. In addition, replacement sliding patio doors should conform to the applicable standards as follows:

o Aluminum sliding patio doors should conform to ANSI/AAMA 402.9-1977, "Voluntary Specifications for Aluminum Sliding Glass Doors."

- Wood sliding patio doors should conform to NWMA I.S. 3-83, "Wood Sliding Patio Doors." 
Table 10. Standards for Replacement Doors

Material or Product

Criteria for Eligibility(1), (2), (3)

conformance to:

Replacement Doors

- Hinged Swinging Doors

- Stee1 ............................. (4) 100-83

- Wood

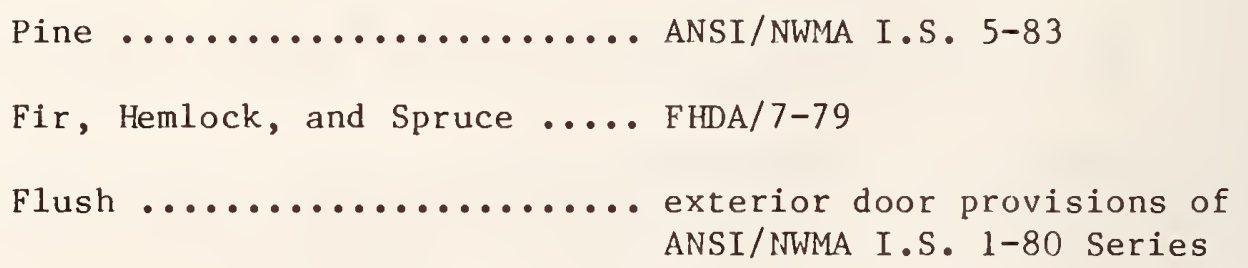

- Sliding Patio Doors

- Aluminum ..................... Allst/AAMA 402.9-1977

- Wood ....................... NWMA I.S. 3-83

(1) The coefficient of thermal transmittance for replacement hinged (swinging) doors should not be greater than $0.45 \mathrm{Btu} / \mathrm{h} \cdot \mathrm{ft}{ }^{2} \cdot{ }^{\circ} \mathrm{F}$.

(2) Sliding patio doors should have multiple glazing and metal frames should include a thermal break to reduce heat flow.

(3) If multiple glazing is used, sealed insulating glass units are preferred and should conform to ASTM E 774-81, "Standard Specifications for Sealed Insulating Glass Units."

(4) SDI indicates Steel Door Institute. 
2.5.4 Areas of Application. When warranted because of excessive heat flow and air infiltration, any residential exterior door, or door and frame assembly, may be replaced. Installation should not violate any applicable existing local building-related code.

2.5.5 Commentary. Guidelines are not available to assist the homeowner in deciding whether or not an exterior door, or door and frame assembly, should be replaced with a thermally-improved door. Defects in an existing prime door such as poor fitting, warpage, cracks and holes which cannot be overcome adequately with weatherstripping and repairs may indicate a need for its replacement. Installation of weatherstripping and storm doors are alternative methods to reduce heat flow and air infiltration through existing exterior doors. Considering Petersen's findings [3] that in many cases storm doors are not cost-effective, it may be assumed that replacement doors may in many cases not be cost-effective. Keeping in mind the purposes of the Weatherization Assistance Program, it is advisable that replacement doors only be considered as a retrofit measure in extreme cases when alternative methods for reducing heat flow through prime door and frame assembles are considered to be inadequate.

Thermally-improved doors require low rates of heat flow and air infiltration. The requirement for a $0.45^{\circ} \mathrm{Btu} / \mathrm{h} \cdot \mathrm{ft}^{2}{ }^{\circ} \mathrm{F}$ thermal transmittance in the case of hinged doors, or for multiple glazing and thermal breaks in metal frames in the case of sliding patio doors, is intended to provide low rates of heat flow, and therefore increased benefits for energy conservation. Many types of exterior doors are available with Uvalues less than $0.45 \mathrm{Btu} / \mathrm{h} \cdot \mathrm{ft}^{2}{ }^{\circ} \mathrm{F}$, as indicated in table $9 \mathrm{~A}$ of Chapter 23 of the ASHRAE Handbook of Fundamentals [37]. In addition, it is noted that the maximum U-value of insulated steel doors conforming to the requirements in ANSI/ISDSI-107 (1983), "Thermal Performance Standard for Insulated Steel Door Systems," is $0.25 \mathrm{Btu} / \mathrm{h} \cdot \mathrm{ft}^{2} \bullet^{\circ} \mathrm{F}$.

ASHRAE Standard 90-80, "Energy Conservation in New Building Design," recommends that the air infiltration rates through hinged doors and sliding patio doors not exceed $0.5 \mathrm{cfm}$ per square foot of door area, respectively. The Standards ANSI/AAMA 402.9-1977 and NWMA I.S. 3-83 have requirements for maximum allowable rate of air infiltration through sliding patio doors. These requirements may be specified since sliding patio doors are normally installed as a door and frame assembly. The assembly including weatherstripping may be manufactured to provide a tight seal between the sliding door and the frame.

It may be difficult to attain the ASHRAE Standard 90-80 recommended maximum rate of air infiltration for replacement hinged doors, or door and frame assemblies. In either case, the air infiltration will depend upon the quality of installation. The door should be installed straight, plumb, level, and without warping. It should fit tightly in the frame and be properly weatherstripped, including placement of a threshold. Proper installation of hinged doors is required if the ASHRAE Standard 90-80 recommended maximum rate of air infiltration of $0.5 \mathrm{cfm}$ per square foot of door area is to be attained. 
New door and frame assemblies should be properly caulked and sealed into the wall of the residence to reduce air infiltration.

\subsection{CAULKS AND SEALANTS}

2.6.1 Definition. Caulks and sealants are nonrigid materials placed in joints of buildings to reduce the passage of heat, air, moisture, and dust. The terms caulk and sealant are often used interchangeably. On the other hand, many producers and contractors refer to the lower performance materials as caulks, and to the higher performance materials as sealants.

2.6.2 Materials. Materials used as caulks and sealants have been grouped in three classifications according to their performance [40]. The materials in each class are listed below along with a category for putty and glazing compounds.

\subsubsection{Basic Performance.}

- Oil and Resin Base Caulks

2.6.2.2 Intermediate Performance.

- Acrylic (Solvent Type) Caulks

- Butyl Rubber Sealant (or Caulk)

- Chlorosulfonated Polyethylene

- Latex Sealing Compounds

2.6.2.3 High Performance.

- Polysulfide

- Polyurethane

- Silicone

2.6.2.4 Putty and Glazing Compounds. There are two types of compounds generally used for sealing relatively small glass panes. The two types are putty and glazing compounds. For larger glass windows (e.g., picture windows) sealants from the intermediate and high performance classes are used.

2.6.3 Criterion. Caulks and sealants for retrofitting residences should conform to the applicable ASTM Standard or Federal Specification given in table 11 . 
Table 11. Standards for Caulks and Sealants

Material or Product

Criteria for Eligibility

conformance to:

Caulks and Sealants

- Putty .......................... TT-P-00791B

- Glazing Compound ..............ASTM C 669-75 (1981)

- 0 il and Resin Base ............ASTM C 570-72 (1978)

- Acrylic (Solvent Type) .......... F.S. TT-S-00230C

- Buty1 Rubber .................... TT-S-001657

- Chlorosulfonated Polyethylene ... F.S. TT-S-00230C

- Latex Sealing Compounds ......... ASTM C 834-76 (1981)

- Elastomeric Joint Sealants ...... ASTM C 920-79 (normally considered to include polysulfide, polyurethane, and silicone)

- Cellular Elastomeric Preformed Gasket \& Sealing Materials ...... ASTM C 509-79

2.6.4 Areas of Application. Caulks and sealants used for retrofitting should be installed in joints of residential housing such as those associated with the following:

- Window frames

- Door frames

- Window and door glazing

- Joints between walls and foundations or slabs

- Wall to wall joints

- Siding joints

- Skylights 
o Ducts, vents, and other penetrations through walls

- Air conditioners to window joints

- Attic floor/chimney/siding gaps

o Fuel-oil pipe and other similar designed breaks in the exterior surface

- Window frame/storm window joint.

2.6.5 Commentary. The level of performance of a caulk or sealant is somewhat related to the cost of the product. Caulks and sealants classified as basic performance are usually lowest in cost and those classified as high performance tend to be the highest in cost. A more expensive product will in general be expected to last longer. Thus, a high initial investment may more than pay for itself by eliminating additional expense at a later date because of re-installation costs. Even a low quality caulk or sealant will save energy by reducing air infiltration. In the case of all classes of caulks and sealants, their proper application is imperative for achieving satisfactory performance. Guidelines for applying caulks and sealants are given in section 3.6 .

Caulks and sealants for retrofitting residences are generally available in cartridges for use in caulking guns, although other means of application such as putty knives are used. For architectural attractiveness, some generic types of caulks and sealants are available in several colors. Others may be painted to match the color of the residence. Information pertaining to color and painting should be available on the cartridge or container in which the caulk or sealant is sold.

Caulks and sealants should be labeled on the cartridges or containers as conforming to the applicable ASTM or Federal Specification so that compliance to the criterion stated in section 2.6 .3 may be determined.

\subsection{WEATHERSTRIPPING}

2.7.1 Definition. Weatherstripping consists of narrow strips of material placed over or in moveable joints of windows and doors to reduce the passage of air and moisture.

2.7.2 Materials. Various types of weatherstripping are available for retrofitting. In general most can be applied to both windows and doors. However, others are made specifically for doors. Examples of weatherstripping are given in the following sections.

\subsubsection{Weatherstripping for Both Windows and Doors}

o spring bronze strips

- felt strips

- adhesive backed foam strips 
o adhesive backed sponge rubber strips

- bristle brush strips

- hollow vinyl cord

- sponge rubber gasket

- metal wrapped vinyl strips

o metal wrapped felt strips

\subsubsection{Weatherstripping for Hinged Doors}

o door bottom strips

o door bottom sweeps

o door shoes

o vinyl bulb threshold

- interlocking threshold

o magnetic strips

2.7.3 Criterion. Any commercially available material which is marketed as weatherstripping should be eligible (table 12). It should not be required that the weatherstripping conform to any specification or special provision.

2.7.4 Areas of Application. Materials used as weatherstripping may be applied to all windows and exterior doors in residences or to doors between heated and unheated rooms.

2.7.5 Commentary. This report is concerned with weatherstripping normally sold in building supply houses, hardware stores, and home improvements centers. Weatherstripping is one of the easiest retrofit materials or products to install. The only requirement for acceptance in the DOE Weatherization Assistance Program should be that the material be commercially available and be labeled as weatherstripping.

There are no test methods for demonstrating the efficiency of weatherstripping used for retrofitting. The amount of reduction of air flow will depend upon the tightness of the door or window being weatherstripped, and the degree to which compression or deflection of the weatherstripping seals the air gap of the door or window. Certain weatherstripping may not be suitable for all doors and windows because of the gap size of the joint. Proper selection and installation of weatherstripping are important to achieve maximum reduction of air flow.

There is a range of quality among the various weatherstrippings that the homeowner may purchase. For example, it has been reported that the foam plastics are inferior to the metal strips or vinyl cord [41]. Even an inferior quality product will save energy by reducing air infiltration at windows and doors. Such materials are, therefore, recommended for acceptance. The homeowner should be aware that inferior quality weatherstripping may not perform as well as better quality products and may have to be replaced more frequently. Better quality products are more durable and tend to retain their ability to reduce air infiltration for a longer period of time. 
Table 12. Weatherstripping Criterion

Material or Product

Criterion for Eligibility

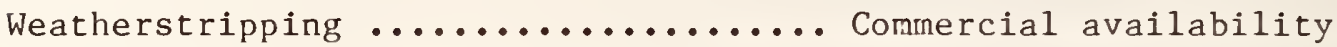

\subsection{VAPOR RETARDERS}

2.8.1 Definition. A vapor retarder is a material which provides a high resistance to the transmission (flow) of water vapor through building and insulating materials due to water vapor pressure difference. The principal purpose of vapor retarders is to preclude or reduce moisture accumulation including condensation of water vapor within insulation and other building materia?s.

2.8.2 Materials. The materials listed below, when installed as recommended, provide water vapor retarders. Vapor retarder materials should be water resistant, puncture resistant, abrasion resistant, tear resistant, fire resistant, noncorrosive, rot and mild resistant, and of sufficient tensile strength, in addition to a high resistance to water vapor transmission.

2.8.2.1 Membrane Retarders are flexible and non-load bearing, and are supplied in a roll form or as an integral part of thermal insulation. These include metal foils, coated felts and papers, laminated foil and treated papers, and plastic films and sheets. Accessory items, such as tape and adhesives, may be required for sealing joints.

2.8.2.2 Mastic, Coating, and Paint Retarders are field applied semi-liquid compositions having high resistance to water vapor transmission after curing. The ingredients of these retarders include bitumens (asphalts), resins or polymers, pigments, fillers, and volatile solvent or water. Paints which have been used as vapor retarders include alkyds and aluminum pigmented alkyds, polyurethanes, epoxies, and rubber based paints. It would be desirable to have the water vapor permeability of paints stated on the containers.

2.8.2.3 Structural Retarders may be formed from rigid or semi-rigid materials of low permeability which form a part of a structure. They include reinforced plastics, aluminum, stainless steel, and insulating materials which are relatively impervious to water vapor flow due to their physical structure and composition. They require careful sealing of joints and seams. These materials are generally not used as vapor retarders in residential housing.

2.8.3 Criterion. The naterials used for water vapor retarders should conform to provisions cited in ASTM C 755-73 (1979), "Standard Recommended 
Practice for Selection of Vapor Barriers for Thermal Insulations," and be installed in areas listed in section 2.8.4. Vapor retarder materials should have a permeance not greater than 1 perm, when tested according to the dessicant methods described in ASTM E 96-80 (table 13).

2.8.4 Areas of Application. Materials used for water vapor retarders may be applied in residences to the following areas: (1) warm (winter) side of opaque exterior walls, (2) warn (winter) side of flat roofs and ceilings under ventilated attic spaces, (3) generally on the warm (winter) side of floors over unheated basements and crawl spaces depending on the moisture and temperature in these areas, ${ }^{*}$ and (4) over ground or soil in crawl spaces. Membrane vapor retarders, when installed in occupiable areas, should be covered to prevent damage or an increased risk of fire. Vapor retarders should not be applied over existing insulation in cases where the existing insulation is to be covered with new insulation.

Table 13. Standards for Vapor Retarders

Material or Product

Criterion for Eligibility

Vapor retarders

selected according to the provisions cited in ASTM C 755-73 (1979); permeance not greater than 1 perm when determined according to the dessicant method described in ASTM E 96-80

2.8.5 Commentary. Increased amounts of insulation in the walls, roofs, attics, ceilings, and floors of residences to reduce heat through these components requires attention to the increased possibility of excessive accumulation of moisture in them [42]. Little data have been published in this regard, particularly for the extremely cold climates (upper mid-West) of the United States. Limited data from field surveys conducted in Oregon [43] and in the midwest, northeast, and mid-Atlantic regions [44] have indicated that in general moisture related problems were not found which could be attributed to the retrofitting of insulation in the sidewalls of the inspected residences.

* The absolute humidity in crawl spaces may be higher than that indoors, particularly during the summer. In such cases, positioning of the vapor retarder on either the warm (winter) side or cold side of the insulation should be considered based on specific moisture and temperature conditions. 
In addition to the entry of water into the building envelope components through means such as rain leaks and burst pipes, moisture enters these components by both vapor diffusion and air leakage. Historically moisture control in buildings focused on vapor diffusion pathways. Achenbach and Trechsel [45] have recently reviewed current guidelines for controlling condensation in insulated building envelopes. Presently, as indicated for example by Sherwood and TenWolde [46], air leakage is also considered as a major source of moisture in building exterior components.

The possibility of excessive accumulation of moisture in building envelope components may be prevented by one or more of the following measures :

o providing a vapor retarder to limit vapor entry

- providing air leakage barriers to limit vapor entry

- reducing the indoor relative humidity (vapor pressure) by ventilation or other means

o making the cold side of walls, roofs, attics, ceilings, and floors more permeable to the escape of water vapor.

To minimize the risk of problems associated with mositure migration, the Department of Energy developed the moisture control practices listed below for the Residential Conservation Service (RCS) Program [38]. The practices where given as a function of the area (condensation zone) in which the residence was located, as presented in figure 1 , and varied slightly depending upon the type of insulation. In general, these moisture control practices were as follows [38]:

- Vapor retarders are required in condensation zones 1 and 2 where the installation of a vapor retarder is no more difficult and costly to install than in new buildings. In all cases, a vapor retarder is required in condensation zone 1 in high humidity rooms such as bathrooms and unvented kitchen and laundry rooms.

o The sealing of cracks on the interior side of exterior walls and ceilings of high humidity rooms is required in condensation zone 1 .

- For condensation zone 2, the same precautions in high humidity rooms are recommended, but not mandatory.

- In zone 1 and 2, in attics which have existing insulation, a vapor retarder (paint) is recommended.

In addition it was recommended [38] that additional precautions be taken in cases where the residence may have a high indoor relative humidity, such as: 
- Homes with an area of less than $800 \mathrm{ft}^{2}$;

- Homes with less than $250 \mathrm{ft}^{2}$ per occupant;

- Homes with tight wall and ceiling construction and weatherstripped windows and doors;

- Electrically heated homes or homes with a heating system which uses outside combustion air; and

- Homes that are humidified during the winter.

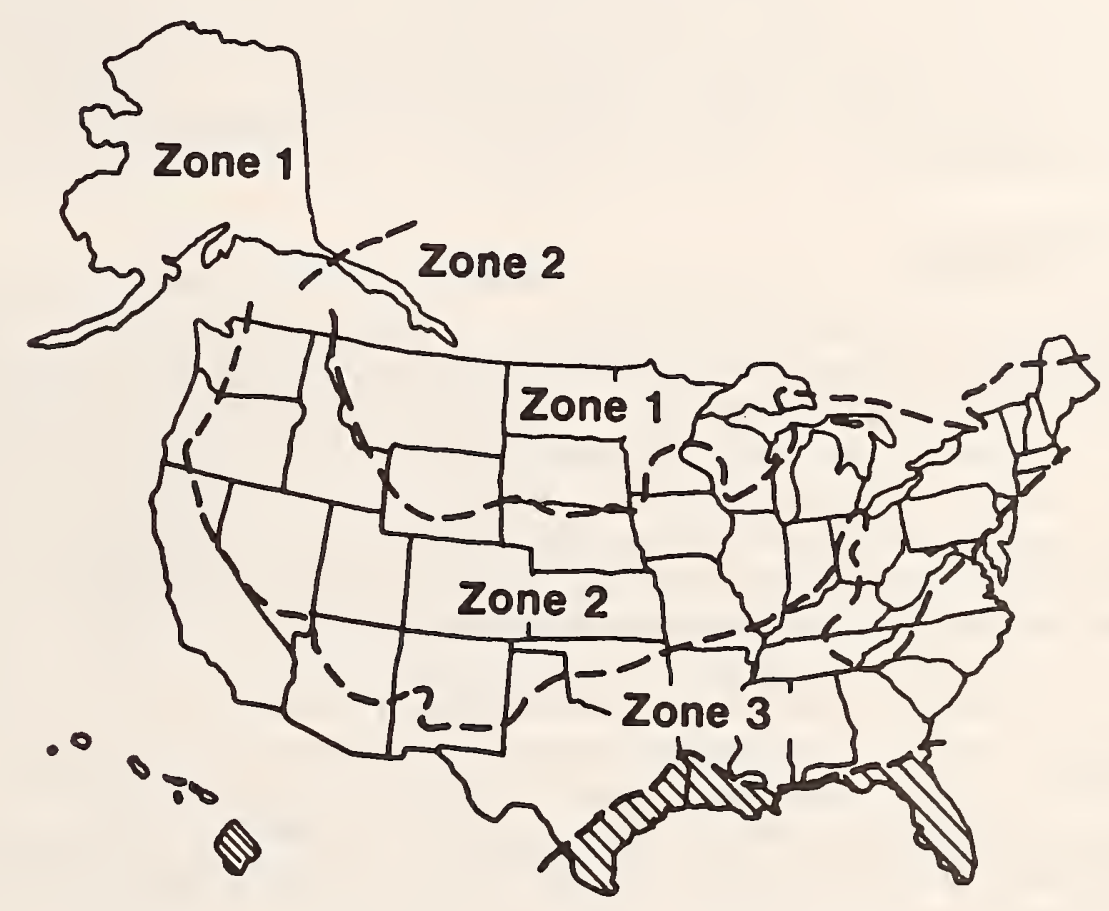

Figure 1. Condensation zone map (from reference 38 )

The additional precautions for the RCS Program [38] included the following:

- Caulk or seal openings at the interior surface of the exterior walls and in the ceiling that permit convection of room air into the wall cavity or through the ceiling (zones 1 and 2 ). 
- Apply low permeability paint or wallpaper to all untiled interior surfaces of exterior walls unless they are already covered with such materials. Low permeability paints and wallpapers have a permeance of less than one perm as defined in ASTM C 755-73 (1979).

o Do not caulk or seal exterior surfaces of outside walls around window and door frames and at the joint between foundation and wall except as required to prevent rain leakage into the wall.

o Vent clothes dryer to outdoors (zones 1 and 2).

o Do not dry laundry indoors unless additional natural ventilation is provided by opening windows or an exhaust fan is running.

- If the exterior of a house being retrofitted has a low-permeability finish (e.g., metal, plastic, or heavily painted wood) steps should be taken to open up the siding construction in ways that would increase outdoor venting of the wall without increasing rain penetration.

\subsection{CLOCK THERMOSTATS}

2.9.1 Definition. A clock thermostat is a temperature control device for interior spaces incorporating two or more adjustable temperature control points and a clock or timer for switching from one control point to an other. Only one control point regulates the interior space temperature at one time. A temperature control point is the mean value of the air temperature at the thermostat under specified operating conditions. A clock thermostat may be used to regulate the operation of a central heating unit and/or an air-conditioning system. Clock thermostats are also available for use with heat pumps.

\subsubsection{Products. Clock thermostats may be classified as follows:}

2.9.2.1 Electro-mechanical Clock Thermostat. This is a thermostat which combines two temperature control points and a clock in a single unit. The clock may be operated using batteries or through direct wiring to a power source. After the setback period is fixed, the thermostat automatically switches between the normal and setback temperatures at least once every 24 hours. Newer units allow more than one setback every 24 hours.

2.9.2.2 Micro-electronic Clock Thermostat. This is a thermostat similar in principle to the electro-mechanical clock thermostat in so far as at least two temperature control points and a timer are incorporated in one unit. However, this thermostat uses a microprocessor to give much more flexibility in temperature and time resetting than the electro-mechanical type. For example, options for week-end setback different than those used during the week are available. 
2.9.3 Criterion. For a clock thermostat, the thermostat portion should conform to the provisions prescribed in National Electrical Manufacturers Association (NEMA) Standards Publication DC 3-1978 entitled, "Low Voltage Room Thermostats," or NEMA Standards Publication DC 15-1979 entitled "Line-Voltage Room Thermostats," depending upon the type of thermostat (table 14). In addition, when the thermostats are tested according to the methods described in Part 4 of NEMA DC 3-1978 or NEMA DC 15-1979, the following requirements should be met:

o the operating differential* should not exceed $2^{\circ} \mathrm{F}$, and

o the effective operating droop** should not exceed $4^{\circ} \mathrm{F}$.

The thermostats should be labeled as meeting the provisions of the standards as well as those for operating differential and effective operating droop.

2.9.4 Areas of Application. Clock thermostats may be applied in residences as replacements of existing thermostats which control interior space temperatures.

2.9.5 Commentary. NEMA Standards Publications DC 3-1978 and DC 15-1979 were not developed specifically for clock thermostats. The standards do allow for auxiliary thermostat components for resetting or for changing temperature control points, as described in section 2.03 of NEMA DC 3-1978 and Section 2.04 of NEMA DC 15-1979, respectively.

Part 4 of NEMA DC 3 or NEMA DC 15 gives performance tests including operating differential and droop tests to be conducted on thermostats. However, levels of performance have not been specified in these NEMA Standards. Levels of performance are specified within the criterion for eligibility of clock thermostats in the DOE Weatherization Assistance Program to help assure that the thermostats will function satisfactorily without diminishing the comfort of the residence. These levels of performance specified here were based on the performance of some presentlyavailable thermostats which did not have setback capability. It is noted that Kao et al [47] have recently developed a thermostat model which may be used in conjunction with building and plant models to evaluate and predict the performance of a dynamic building system.

* The operating differential is the difference between cut-in and cut-out points as measured at the thermostat under specified operating conditions.

** The droop is the deviation in the cut-in point which results from a change in the duty cycle, heating load, or cooling load. 
Table 14. Standards for Clock Thermostats

Material or Product

Clock Thermostats

NEMA(1) DC 3-1978 or NEMA

DC 15-1979 and performance

test requirements $(2)$

(1) NEMA indicates National Electrical Manufacturers Association.

(2) The performance tests requirements are: (1) the operating differential should not exceed $2^{\circ} \mathrm{F}$, and (2) the effective operating droop should not exceed $4^{\circ} \mathrm{F}$ when determined according to the applicable procedures in DC 3-1978 and DC 15-1979.

It has been reported that substantial energy savings can be achieved through temperature setback at night [20,21]. Temperature setback of a thermostat can be accomplished manually. There is no technical reason for requiring the use of clock thermostats. However, there are practical reasons for considering their use such as convenience and comfort to the homeowner. For example, an individual may forget at night to use manual setback or may not want to arise in a cool house in the morning. Automatic control of the setback eliminates the human element and assures regular night setback with its resulting energy savings. Although some clock thermostats may only function on one cycle (setback) a day, they may be nevertheless set back manually at other times whenever the need arises. The cost-effectiveness of a clock thermostat varies with the amount of space or heating capacity it controls and the duration of the heating season.

\subsection{REPLACEMENT GLAZING}

2.10.1 Definition. Replacement glazing denotes the replacement of broken or missing glazing from prime windows and exterior doors. Excessive air infiltration through broken windows will reduce the effectiveness of other retrofit measures. Consequently, broken or missing glazing should be replaced as a first step in retrofitting a residence for energy conservation.

2.10.2 Materials. Replacement glazing should be window glass or plastic. Safety glazing may be used or required in some applications.

2.10.3 Criterion. Replacement glazing should have a minimum thickness of $\overline{1 / 16}$ inch. Safety glazing is normally required in doors and must 
conform to the requirements of 16 CFR Part 1201, "Safety Standard for Architectural Glazing Materials."

2.10.4 Areas of Application. Replacement glazing may be applied to repair any broken or missing window pane in a prime window or exterior door.

2.10.5 Commentary. The requirements of 16 CFR Part 1201 are mandatory and supersede local and national code requirements. It is noted that this Safety Standard does not cover glazing materials used in the manufacture and construction of windows. In some instances, it may be advisable to use safety glazing in windows because of their size or location.

Replacement glazing should be properly secured in the sash and puttied and sealed to prevent air infiltration. In addition, if a window will not remain tightly closed (for example, a double hung window whose top section slides open) during the heating season, steps should be taken to keep the window closed by installing a sash latch or other means. Thickness of replacement glazing greater than 1/16 inch may be necessary for some applications depending upon the size of the window.

The intent of the replacement glazing criterion is to eliminate excessive air infiltration through broken windows. Consistent with the intent of the criterion, other defects such as cracks, holes, or missing boards and planks in the exterior envelope of the building should be repaired. Repairs may be accomplished by using appropriate building materials available at local hardware stores, lumber yards, home-improvement centers, or similar establishments.

Table 15. Replacement Glazing Criterion

Materials Criterion for Eligibility

Replacement glazing Minimum thickness of $1 / 16$ inch. Safety glazing should conform to requirements of 16 CFR Part 1201 and is required in doors. 
This report is not intended to be a manual for the installation of retrofit materials and products. Many installation brochures and manuals have been prepared since the mid-1970s, when in general the public hecame aware of the benefits of weatherizing residences to conserve energy and reduce heating and cooling costs. The Department of Energy prepared "Project Retro-Tech, Home Weatherization Manual [48]." This manual was designed for use in inspecting and evaluating homes to determine if weatherization measures are needed and gives directions for selecting appropriate weatherization materials. Trechsel and Launey [38] published "Criteria for the Installation of Energy Conservation Measures" which presented installation practices for retrofit materials and products. In addition, this document discussed major technical issues such as moisture migration in retrofitted residences, and the effects of the installation of insulation on residential electrical systems. Other installation manuals are: The U.S. Department of Housing and Urban Development publication, "Energy Conservation for Housing: A Workbook" [18], and the NAHB Research Foundation's "Insulation Manual-Homes/Apartments" [49] which discusses all aspects of insulation including proper installation. In addition, many "do-it-yourself" guides are available in bookstores and provide instructions to homeowners and to non-professional inşallers for the installation of retrofit items. One example is "The Illustrated Guide to Home Retrofitting for Energy Savings [50]." Finally, many manufacturers and trade associations have available pamphlets describing the correct installation of their products. Often these pamphlets are available where the product is sold or may be obtained upon request from the manufacturer or trade association.

Section 2 of this report presents recommended criteria for acceptance of retrofit materials and products to assure their quality and safe use. However, proper retrofitting requires more than quality materials and products. Proper installation of retrofit materials and products is a necessity. A superior material may be less effective in saving energy if improperly installed.

This section points out certain precautions that must be taken in the installation of retrofit materials and products. Following these precautions will assist the homeowner in the correct installation of the material.

\subsection{INSULATION}

- When a vapor retarder is attached to the insulation, and the insulation is being applied to an uninsulated wall or ceiling, the vapor retarder should be applied towards the warm (winter) side of the wall or ceiling.

- When adding insulation on top of existing attic floor insulation, do not use a vapor retarder over the existing insulation.

- For air-conditioning applications, duct insulation should contain a vapor retarder on the outside (warm-side) surface to prevent condensation on the duct and in the insulation. For heating and airconditioning applications, any air leaks in the ducts should be sealed with aluminum duct tape or similar material prior to adding insulation. 
o When insulating attics, do not cover ventilation openings in attic soffits and gables. Insulated attics should be ventilated. The U.S. Department of Housing and Urbah Development's Minimum Property Standards (MPS) [51] has the following guidelines for attic ventilation:

a Provide cross ventilation for each separate space with ventilating openings protected against the entrance of rain and snow.

b. Ratio of total net free ventilating area to area of ceiling shall be not less than $1 / 150$, except that ratio may be $1 / 300$ provided:

(1) A vapor retarder having a transmission rate not exceeding one perm is installed on the warm side of the ceiling, or

(2) At least 50 percent of the required ventilating area is provided by ventilators located in the upper portion of the space to be ventilated (at least $3^{\prime}-0^{\prime \prime}$ above eave or cornice vents) with the balance of the required ventilation provided by eave or cornice vents.

(3) Attic space which is accessible and suitable for future habitable rooms or walled-off storage space shall have at least $50 \%$ of the required ventilating area located in the upper part of the ventilated space as near the high point of the roof as practicable and above the probable level of any future ceiling.

- When insulating floors over unheated crawl spaces where earth is uncovered, special attention should be made to ensure adequate natural ventilation of the crawl space. Placement of a vapor retarder on the ground of the crawl space can be an effective means of reducing summer time moisture accumulation in these areas. In a Tennessee Valley Authority field study of moisture control in energy-efficient homes, Jennings [52] reported that a common source of moisture leading to condensation problems within the house was water vapor evaporating from the surface of the ground in a crawl space. He indicated that it could be reduced by as much as 90 percent by installing a vapor retarder to cover the ground. The MPS guidelines [51] for crawl space ventilation and covering are as follows:

a. The space between the bottom of the floor joists and the earth under any building (except such space as is occupied by a basement or cellar) shall be provided with a sufficient number of ventilating openings through foundation walls or exterior walls to ensure ample ventilation, and such openings shall be covered with a corrosionresistant wire mesh not greater than $1 / 2$ in. nor less than $1 / 4$ in. in any dimension. The minimum net area of ventilating openings shall not be less than 1 sq ft for each 150 sq $\mathrm{ft}$ of crawl space area. One such ventilating opening shall be within $3 \mathrm{ft}$ of each corner of said building. 
Exceptions: (1) Ventilation openings may be vented to the interior of buildings where warranted by climatic conditions; (2) the total area of ventilation openings may be reduced to $1 / 1500$ of the under floor area where the ground surface is treated with an accepted vapor retarder material, and one such ventilation opening is within $3 \mathrm{ft}$ of each corner of said buildings. The vents may have operable louvers, and (3) ventilation openings may be omitted on one side.

It is noted that vents in crawl spaces should be closed during the heating season, but it is essential that they be opened after the heating season.

- Retrofitting walls (and other building elements) by the addition of loose-fill or other insulations may increase the possibility of moisture accumulation in the insulation, sheathing, and siding, particular in cold climates [42, 46]. For an overview of practices for the control of moisture, the reader is referred to the commentary (section 2.8.5) accompanying the criteria for vapor retarders in this report.

- Since the effectiveness and physical condition of thermal insulation can be deteriorated if the insulation becomes wet, any leaks in walls, roofs, and other envelope components which are to be insulated should be repaired before retrofitting.

- The addition of insulation to walls, floors, ceilings, attics, and other building elements should not decrease the overall fire safety of the residence. Fire safety requirements for thermal insulating materials are given in section 2.1 .3 .1 and discussed in sections 2.1.4 and $2 \cdot 1 \cdot 5$.

- When insulating walls, floors, and other building envelope components which contain water pipes, attention should be given to assure that addition of the insulation will not result in freezing of the water in the pipes.

- Retrofitting cavity-walls with loose-fill or other insulations generally requires the use of special equipment. Operators of this equipment should be familiar with their use to assure proper application.

- Loose-fill insulation added to ceilings and walls should be of the proper fill density. The installed insulation should not contain excess voids or air spaces. Densities normally recommended by industry are as follows: the fill density of cellulose insulation should be 2 to $3 \mathrm{lb} / \mathrm{ft}^{3}$ for ceilings and 3 to $4 \mathrm{lb} / \mathrm{ft}^{3}$ for walls; for glass fiber insulation 0.7 and $2 \mathrm{lb} / \mathrm{ft}^{3}$ for ceilings and walls, respectively; for slag and rock wool insulations 2 and $2.51 \mathrm{~b} / \mathrm{ft}^{3}$ for ceilings and walls, respectively. These values can be used to calculate needed amounts of these insulations. 
- Storm windows should be securely fastened in place and should be straight; plumb, level, and without distortion to assure satisfactory contact to the prime window frame.

- Storm windows should be sealed according to the manufacturer's instructions. Proper caulking between the storm window frame and the prime window frame is necessary to assure water tightness and to limit air infiltration. Some air exchange between the outdoors and the space between the prime and storm windows is desirable to prevent condensation on the window on the exterior of the house.

o Weep holes in the storm window frame should not be blocked.

- Steps should be taken to prevent galvanic corrosion which is a form a deterioration resulting from the electrochemical reaction which occurs when certain dissimilar metals are in contact in the presence of moisture. In the installation of metal windows (and doors), dissimilar metals that should not be in direct contact are aluminum and steel or iron, aluminum and bronze, and aluminum and brass. Aluminum should only be used in contact with other aluminum or stainless steel, and not with other dissimilar metals [53].

- Section 6 of ASTM E 737, "Standard Practice for Installation of Storm Windows, Replacement Windows, Multi-Glazing, Storm Doors, and Replacement Doors," provides guidelines on the installation of storm windows. It is noted that this ASTM standard was prepared for use by professional installers and not untrained homeowners.

\subsection{STORM DOORS}

- Storm doors when fastened in place should be straight, plumb, level, and without distortion to assure satisfactory contact to the prime door frame.

- Storm doors should be installed according to the manufacturer's instructions. Proper installation is necessary to minimize air infiltration and assure watertightness.

- Steps should be taken, as discussed in section 3.2, to avoid galvanic corrosion problems arising from the installation of metal storm doors.

- Section 10 of ASTM Standard Practice E 737 provides guidelines on the installation of storm doors.

\subsection{REPLACEMENT WINDOWS}

- Assure that the framing members to which the replacement window is to be installed are in satisfactory condition. Framing members which are 
decayed, rotted, or have other deterioration problems should be replaced before installation of the replacement window.

- Follow the manufacturer's instructions for installation.

- Seal or caulk joints between the replacement window frame and the wall of the residence to eliminate this path of air and water penetration.

- Check that operable sashes open easily after installation and painting.

- Check that weatherstripping makes satisfactory contact with appropriate surfaces.

- Section 7 of ASTM E 737 provides guidelines on the installation of replacement windows.

\subsection{REPLACEMENT DOORS}

- Assure that the framing members to which the replacement door is to be attached are in satisfactory condition. Framing members which are decayed, rotted, or have other deterioration problems should be replaced before installation of the replacement door.

- Replace the existing threshold if it is deteriorated beyond repair.

- Follow the manufacturer's instructions for installation.

- Seal or caulk joints between the replacement door frame and the wall of the residence to eliminate this path of air and water penetration.

- Check that the door opens easily after installation and painting.

- Check that the replacement door is properly weatherstripped and that weatherstripping makes satisfactory contact with appropriate surfaces.

- Section 11 of ASTM E 737 provides guidelines on the installation.

\subsection{CAULKS AND SEALANTS}

- Follow manufacturer's directions as indicated on label of the cartridge or can, or in a brochure. Pay particular attention to precautions given for safety in handling the material.

- Remove from the joint to be caulked all dust, dirt, particles, oil, grease, loose caulking, and loose paint before placing the new compound into the joint.

- Manufacturers sometimes recommend a primer or surface conditioner for ceriain surfaces. This is done to produce a strong bond of the sealant to the surface. Always use the primer when it is recommended. 
- Whenever possible, do not caulk joints at temperatures below $40^{\circ} \mathrm{F}$ since at low temperatures poor adhesion of the sealant may result.

- Do not apply sealant on wet or damp surfaces, including those on which condensation is present.

- If the joint is $1 / 4$ inch wide or more, use a backup or filler material, if possible. The filler may be any foam or sponge type nonstaining material which is pressed into the joint without completely filling it. A space with a depth of at least $1 / 4$ inch should be left for application of the sealant.

- Tool the sealant with a putty knife or smooth wooden stick to force the sealant against the sides of the joint.

- The placing of masking tape on each surface adjacent to the joint before the caulking operation will help provide for a neat looking joint. Peel away the tape and excess caulking as soon as the work is finished.

- Do not add any liquid or powder to a sealant to change its handling property unless specific instructions are given by the manufacturer.

- Do not heat the sealant unless there are printed instructions to do so.

- ASTM C 797, "Standard Recommended Practices and Terminology for Use of Oil- and Resin-Based Putty and Glazing Compounds," provides guidelines for the application of these materials.

- ASTM C 962, "Standard Guide for Use of Elastomeric Joint Sealants," provides information on the application of these types of sealants.

\subsection{WEATHERSTRIPPING}

- Follow manufacturer's directions as printed on the package or in a brochure.

- Assure that the surface is smooth by removing old weatherstripping, dirt particles, loose paint, and other similar materials which would prevent complete contact of the weatherstripping to the surface.

- Apply adhesive backed weatherstripping to clean and dry surfaces only.

- Apply weatherstripping in one continuous strip along each joint of the door or window.

- Assure that weatherstripping is tight at corners.

- For both door and window applications, assure that the applied weatherstripping makes contact with the fixed and movable sections of the joint (for example, window sash and frame). In general weather- 
stripping should be slightly compressed when the door or window is in a closed position.

\subsection{VAPOR RETARDERS}

- Apply vapor retarders on the warm (winter) side of ceilings and walls

- Do not puncture, rip or tear vapor retarders, since the effectiveness of the retarder may be greatly reduced if openings exist in it.

- Punctured, ripped, or torn vapor retarders should be repaired. Repairs can be made by covering the damaged area with a piece of vapor retarder material secured with kraft paper tape or covering the damaged area directly with a low permeability tape such as aluminum duct tape or PVC tape.

- Combustible vapor retarders such as asphaltic kraft paper should not be left exposed after installation but should be covered to reduce the risk of fire.

- Fit vapor retarders carefully around all joints and penetrations such as duct openings, electrical fixtures and switches, and window or door frames, and seal joints, if possible. For electrical outlet and switch boxes, preformed rubber gaskets are available to seal these locations in the wall against air leakage.

- Section 2.8 .5 of this report contains summary guidelines on the use of vapor retarders.

\subsection{CLOCK THERMOSTATS}

- Follow the manufacturer's instruction for installation.

- Prior to installation the installer should determine whether the characteristics of the device are compatible with the requirements of the heating and/or cooling system with regards to voltage, current ratings, and modes of operation.

- Thermostats should not be installed near heat sources, cold areas (e.g., outside walls), or areas that receive poor air circulation.

- When the installation requires any electrical connections, additional wiring, or electrical components, all and any circuits supplying electrical power to the thermostat and electrically connected devices (i.e., heating and/or cooling unit) should be disconnected at the supply. Some clock thermostats may require installation by a qualified electrician.

- Do not wire the clock into the temperature limit or fan control circuits of the furnace. Whenever the limit control is activated, 
the clock will stop and lose time. An inaccurate clock may discourage the homeowner from using the clock thermostat.

\subsection{REPLACEMENT GLAZING}

- Use proper thickness and size and tightly install using mechanical fasteners, and putty, glazing compound, or sealant to prevent air infiltration.

- Use safety glazing in doors as required by 16 CFR Part 1201, "Safety Standard for Architectural Glazing Materials."

- Sections 8 and 9 of ASTM E 737 provide guidelines on the installation of sealed and unsealed multiple glazing insulating glass, respectively. 


\subsection{REFERENCES}

1. Hirst, Eric and Hannon, Bruce, "Effects of Energy Conservation in Residential and Commercial Buildings," Science, Vol. 205 (17 August 1979), pages 656-661.

2. Seidel, Marquis R., Plotkin, Steven E., and Reck, Robert 0., "Energy Conservation Strategies," Environmental Protection Agency Report EPA-R5-73-021 (July 1973).

3. Petersen, Stephen R., "Retrofitting Existing" Housing for Energy Conservation: An Economic Analysis," National Bureau of Standards (U.S.), Bld. Sci. Ser. 64 (December 1974), 76 pages.

4. "Impact of Improved Thermal Performance in Conserving Energy," National Mineral Wool Insulation Association, Inc., New York, NY, [Ed. Note: Now the Mineral Insulation Manufacturers Association.] (March 1973), 49 pages.

5. "Statistical Analysis of Energy Conservation Trends Using the Annual Housing Survey," U.S. Department of Energy, (October 21, 1983), p. 6 .

6. Chang, Lui-May L. and Grot, Richard A., "Technique for Tracking the Effect of Weatherization Retrofits on Low-Income Housing," National Bureau of Standards (U.S.), NBSIR 83-2676 (April 1983), 50 pages.

7. Crenshaw, Richard and Clark, Roy E., "Optimal Weatherization of Low-Income Housing in the U.S.: A Research Demonstration Project," National Bureau of Standards (U.S.), Bldg. Sci.Ser.144 (September 1982), 166 pages.

8. Dickinson, J. B., Grimsrud, D. T., Krinkel, D. L., and Lipschutz, R. D., "Results of the Bonneville Power Administration Weatherization and Tightening Projects at the Midway Substation Residential Community," Lawrence Berkeley Laboratory, LBL-12742, UC-95d (February 1982), 80 pages.

9. Dutt, Gautam, Lavine, Michael, Levi, Barbara, and Socolow, Robert, "The Modular Retrofit Experiment: Exploring the House Doctor Concept," Princeton University, PU/CEES Report No. 130 (June 1982), 77 pages.

10. Grier, Eunice, S., "How Much Can We Save With Weatherization" in "Optimal Weatherization," Proceedings of the National Conference on Optimal Weatherization (December 1980), pages 1-10.

11. Plunkett, Jerry D., "Conservation - The Key Element of Energy Delivery Systems for the 21 st Century," in "Optimal Weatherization," Proceedings of the National Conference on Optimal Weatherization (December 1980), pages $36-41$.

12. Shepherd, Philip B. and Gerharter, Judith E., "Techniques for Control of Air Infiltration in Buildings," Manville Service Corporation, Report No. FESA-TS-2070 (30 April 1979), 111 pages. 
13. Hirst, Eric, "Reducing Residential Energy Growth," ASHRAE Journal (January 1979), pages 44-46.

14. Hirst, Eric and Jackson, Jerry R., "Euture Energy Use in Residential and Commercial Buildings: Energy Conservation and Economics," Journal of Business Administration, Vol. 10, Nos. 1 and 2 (fall 1978/spring 1979), pages $183-206$.

15. Harrje, David T., Socolow, R. H., and Sonderegger, R. C., "Residential Energy Conservaiton - The Twin Rivers Project," ASHRAE Transactions, Vo1. 83, Pt. 1 (1977), pages 458-477.

16. Hastings, S. Robert and Crenshaw, Richard, W., "Window Design Strategies to Conserve Energy," National Bureau of Standards (U.S), B1dg. Sci. Ser. 104 (June 1977), 209 pages.

17. Burch, D. M. and Hunt, C. M., "Retrofitting an Existing Wood Frame Residence for Energy Conservation - An Experimental Study," National Bureau of Standards (U.S.), NBSIR 77-1274 (July 1977), 157 pages.

18. "Energy Conservation for Housing: A Workbook," U.S. Department of Housing and Urban Development (May 1982).

19. "Retrofitting Homes for Energy Conservation, A Business Guide," NAHB Research Foundation, Inc., Rockville, MD (March 1975).

20. Pilati, David A., "The Energy Conservation Potential of Winter Thermostat Reductions and Night Setback," Oak Ridge National Laboratory, Report ORNL-NSF-EP-80 (February 1975), 27 pages.

21. Nelson, Lorne W., "Reducing Fuel Consumption with Night Setback," ASHRAE Journal (August 1973), pages 41-49.

22. "Thermal Insulation Performance," McElroy, D. L. and Tye, R. P., Eds., ASTM Special Technical Publication 718 (December 1980), 568 pages.

23. "Thermal Performance of the Exterior Envelopes of Buildings," Proceedings, ASHRAE/DoE-ORNL Conference, ASHRAE SP 28, (3-5 December 1979), 1004 pages.

24. "Thermal Performance of the Exterior Envelopes of Buildings II," Proceedings, ASHRAE/DoE Conference, ASHRAE SP 38, (6-9 December 1982), 1125 pages.

25. "Thermal Insulation, Materials, and Systems for Energy Conservation in the '80s," Govan, F. A., Greason, D. M., and McAllister, J. D., Eds., ASTM Special Technical Publication 789, (January 1983), 893 pages.

26. Code of Federal Regulations, "Weatherization Assistance for Low-Income Persons," 10 Part 440 (revised January 1982), pages 245-257. 
27. "Weatherization Assistance Program for Low-Income Persons," Fact Sheet, U.S. Department of Energy (February 1984), 4 pages.

28. "Weatherization Assistance for Low-Income Persons; Notice of Proposed Rulemaking and Public Hearing," Federal Register (U.S.) ( 4 November 1983), pages 51068-51083.

29. "Weatherization Assistance for Low-Income Persons: Final Rule," Federal Register (U.S.), (27 Janauary 1984), pages 3624-3638.

30. Rossiter, Walter J., Jr. and Mathey, Robert G., Eds., "Recommended Criteria for Retrofit Materials and Products Eligible for Tax Credit," National Bureau of Standards (U.S.), NBSIR 75-795 (November 1975), 44 pages.

31. Rossiter, Walter J., Jr. and Mathey, Robert G., Eds., "Criteria for Retrofit Materials and Products for Weatherization of Residences," National Bureau of Standards (U.S.), Tech. Note 982 (September 1978), 75 pages.

32. Kweller, Esher, NBS Report in Preparation.

33. Saayman, H. M., "Phenol-formadehyde Foams for Building Insulation," National Building Research Institute, CSIR, (South Africa), R/BOU 1012 (1983), 5 pages.

34. Cartmel1, M. J. and Brown, R. K., "Polyurea Foam for Retrofit Insulation An Update with Case Studies," J. Thermal Insulation, Vol. 6 (April 1983), pp. 250-262.

35. Langdon, William K., "Morable Insulation," Rodale Press, Emmaus, PA (1980), 379 pages.

36. Kusuda, T. and Bean, J. W., "Savings in Electric Cooling Energy By Use of a Whole-House Fan," National Bureau of Standards (U.S.), Technical Note 1138 (May 1981), 39 pages.

37. ASHRAE Handbook of Fundamentals, Chapter 23, American Society of Heating, Refrigerating, and Air-Conditioning Engineers, Inc., Atlanta, GA (1981).

38. Trechse1, Heinz R. and Launey, Sheila J., "Criteria for the Installation of Energy Conservation Measures," National Bureau of Standards (U.S), Special Publication 606 (July 1981), 203 pages.

39. ASHRAE Handbook and Product Directory - Sytems, Chapter 43, American Society of Heating, Refrigerating, and Air-Conditioning Engineers, Inc., Atlanta, GA (1980).

40. Reference 31 , page 22 .

41. Reference 18, page 34. 
42. Sherwood, G. E., "Moisture Control in Retrofit Insulation," Transactions of the ASAE, Vol. 24, No. 5 (1981), pages 1296-1298.

43. Tsongas, George A., Odell, F. Glen, and Thompson, James C., "A Field Study of Moisture Damage in Walls Insulated Without a Vapor Barrier," Proceedings of the ASHRAE/DoE Conference, "Thermal Performance of the Exterior Envelopes of Buildings," December 3-5, 1979, ASHRAE SP 28, pages $801-815$.

44. Weidt, John L., Saxler, Robert J., and Rossiter, Walter J., Jr., "Field Investigation of the Performance of Residential Retrofit Insulation," National Bureau of Standards (U.S.), Tech. Note 1131 (September 1980), 67 pages.

45. Achenbach, P. R. and Trechsel, H. R., "Evaluation of Current Guidelines of Good Practice for Condensation Control in Insulated Building Envelopes," Proceedings of ASHRAE/DoE Conference, "Thermal Performance of the Exterior Envelopes of Buildings II," December 6-9, 1982, ASHRAE SP 38, pages 1090-1107.

46. Sherwood, Gerald E. and TenWolde, Anton, "Moisture Movement and Control in Light-Frame Structures," Forest Products Journal, Vol. 32, No. 10 (1982), pages 69-73.

47. Kao, James Y., Mastascusa, E. J., and Chi, Joseph, "Low-Voltage Room Thermostat Performance," National Bureau of Standards (U.S.), B1dg. Sci. Ser. 150 (April 1983), 46 pages.

48. "Project Retro-Tech, Home Weatherization Manual," U.S. Department of Energy, DoE/CS-0106 (Revised July 1979), 30 pages.

49. "Insulation Manual - Home/Apartments," 2nd Edition, NAHB Research Foundation, Inc., Rockville, MD (1979), 150 pages.

50. Knight, Paul, "The Illustrated Guide to Home Retrofitting for Energy Savings," McGraw-Hill, New York, NY (1981), 365 pages.

51. "Minimum Property Standards - One and Two Family Dwellings," U.S. Department of Housing and Urban Development, Section 4900.1 (1982), pages $4-9$ and $4-10$.

52. Jennings, Charles W. and Moody, Thomas L., "Field Experiences Underscore the Importance of Moisture Control in Energy-Efficient Homes," TVA/OP/ECR-82/98 (13 September 1982), 15 pages.

53. Reference 34, page 140 . 

APPENDIX A. STANDARDS AND SPECIFICATIONS CITED IN THIS REPORT

1. ANSI

American National Standards Institute Inc.

1430 Broadway

New York, New York 10018

ANSI/AAMA 302.9-1977 - Voluntary Specifications for Aluminum Prime Windows

ANSI/AAMA 402.9-1977 - Voluntary Specifications for Aluminum Sliding Glass Doors

ANSI/AAMA 1002.10-83 - Aluminum Insulating Storm Products for Windows and Sliding Glass Doors

ANSI/AAMA 1102.7-1977 - Voluntary Specifications for Aluminum Storm Doors

ANSI/ISDSI-107 (1983) - Proposed Thermal Performance Standard for Insulated Steel Door Systems

ANSI/NWMA I.S. 1-80 Series - Wood Flush Doors

ANSI/NWMA I.S. 2-80 - Wood Window Units

ANSI/NWMA I.S. 5-83 - Ponderosa Pine Doors

2. ASHRAE

American Society of Heating, Refrigerating and Air-Conditioning Engineers, Inc.

1791 Tullie Circle NE

Atlanta, Georgia 30329

ASHRAE Standard 90-80 - Energy Conservation in New Building Design

3. ASTM

American Society for Testing and Materials

1916 Race Street

Philadelphia, Pennsylvania 19103

C 208-72 (1982) - Insulating Board (Cellulosic Fiber), Structural and Decorative

C 509-79 - Cellular Elastomeric Preformed Gasket and Sealing Material

C 516-80 - Vermiculite Loose Fill Thermal Insulation 


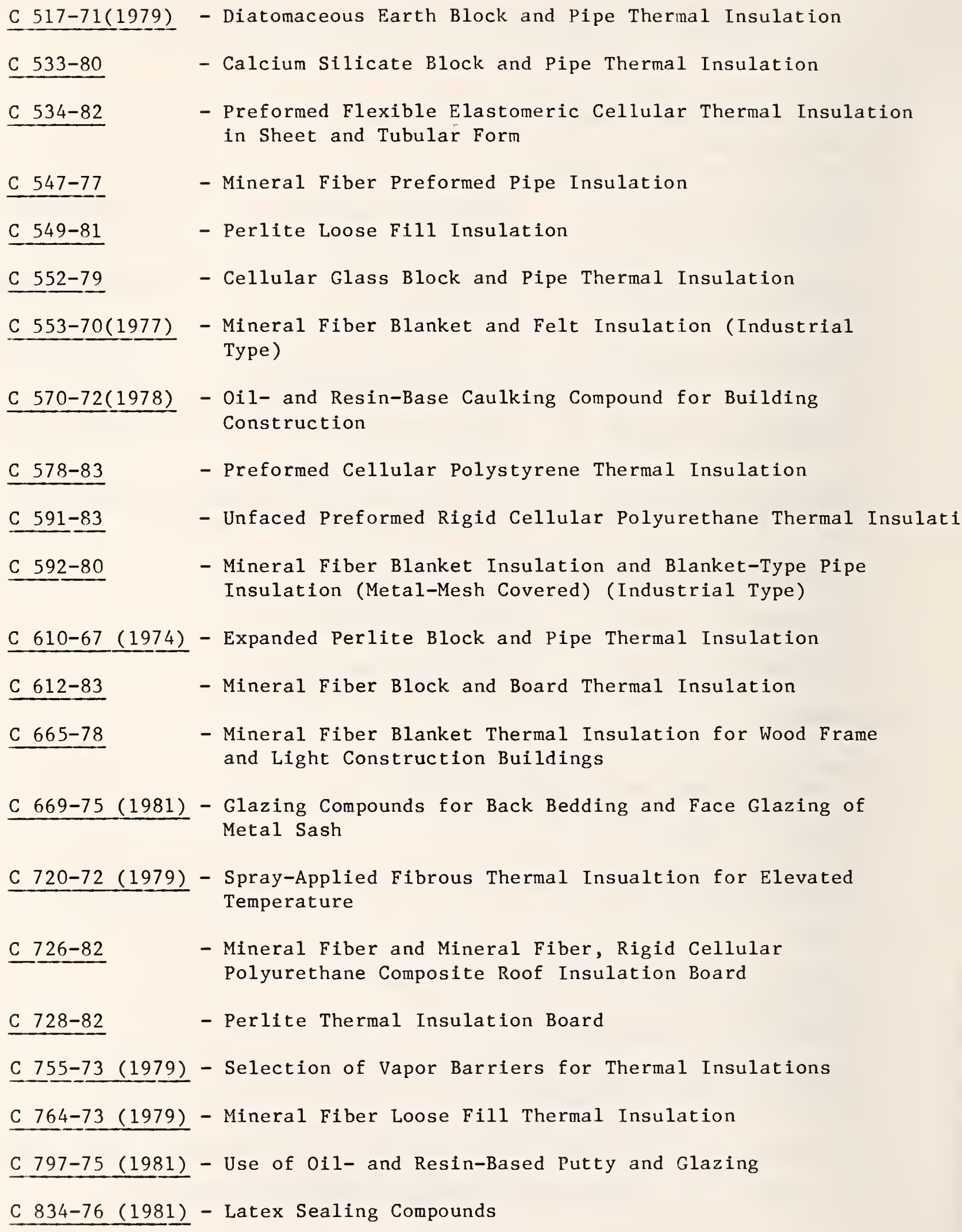


C 892-78

C $920-79$

C $962-81$

C $971-82$

C $984-83$

D 3678-81

D 4099-82.

E $84-81 a$

E 96-80

E 108-83

E 737-80

E 774-81

E $970-83$
- High-Temperature Fiber Blanket Thermal Insulation

- Elastomeric Joint Sealants

- Use of Elastomeric Joint Sealants

- Selection and Application of Insulation Systems for Heating, Ventilating, and Air Conditioning Duct Work

- Perlite Board and Rigid Cellular Polyurethane Composite Roof Insulation

- Rigid Poly(Vinyl Chloride) (PVC) Interior Profile Extrustions

- Poly(Vinyl Chloride) (PVC) Prime Windows

- Surface Burning Characteristics of Building Materials

- Water Vapor Transmission of Materials

- Fire Tests of Roof Coverings

- Installation of Storm Windows, Replacement Windows, MultiGlazing, Storm Doors, and Replacement Doors

- Sealed Insulating Glass Units

- Critical Radiant Flux of Exposed Attic Floor Insulation Using A Radiant Heating Source

4. $\operatorname{CPSC}$

Consumer Product Safety Commission

1111 18th Street NW

Washington, DC 20207

16 CFR Part 1201 - Safety Standard for Architectural Glazing Materials

16 CFR Part 1209 - Interim Safety Standard for Cellulose Insulation

5. Federal Specifications

GSA Business Service Center

Seventh and D Streets, SW

Washington, DC 20407

HH-I-1972/1 - Insulation Board, Thermal, Polyurethane or Polyisocyanurate, Faced with Aluminum Foil on Both Sides of the Foam (8-12-81) 


\begin{abstract}
$\underline{\text { HH}}$ I-1972/2 - Insulation Board, Thermal, Polyurethane or Polyisocynaurate, Faced with Asphalt/Organic Felt, Asphalt/Asbestos Felt or Asphalt/Glass Fiber Felt on Both Sides of the Foam (8-12-81)

HH-I-1972/4 - Insulation Board, Thermal, Polyurethane or Polyisocynaurate, Faced with Gypsum Board on One Side and Aluminum Foil or Asphalt/Organic Felt on the other Side of the Foam (8-12-81)

TT-P-00791B - Putty: Linseed-0il Type, (For Wood-Sash-Glazing) (3-23-71)

TT-S-00230C - Sealing Compound: Elastomeric Type, Single Component (For Caulking, Sealing, and Glazing in Buildings and other Structures) (10-9-70)

TT-S-001657 - Sealing Compound--Single Component, Buty1 Rubber Based, Solvent Release Type (For Buildings and Other Types of Construction) $(10-8-70)$
\end{abstract}

6. FHDA

Fir and Hemlock Door Association

Yeon Building

Portland, Oregon 97204

Industry Standard FHDA/7-79 (12-1-80) - Douglas Fir, Western Hemlock, and Sitka Spruce Doors

7. NEMA

National Electrical Manufacturers Association

2101 L Street NW

Washington, DC 20037

DC 3-1978 - Low Voltage Room Thermostats

DC 15-1979 - Line-Voltage Room Thermostats

8. NFPA

National Fire Protection Association

Batterymarch Park

Quincy, Massachusetts 02269

NFPA 70-1981 - National Electrical Code

9. NWMA

National Woodwork Manufacturers Association 205 West Touhy Avenue

Park Ridge, Illinois 60068

NWMA I.S. 3-83 - Wood Sliding Patio Doors 
10. SDI

Steel Door Institute

712 Lakewood Center North

14600 Detroit Avenue

Cleveland, Ohio 44107

S.D.I. 100-83 - Standard Stee1 Doors and Frames

11. SWI

Steel Window Institute

1230 Keith Building

Cleveland, Ohio 44115

SWI (1983) - Steel Window Specifications 

NBS-114A (REV. 2-8C)

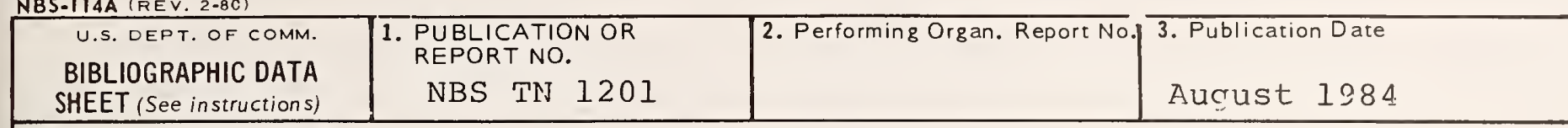

4. TITLE AND SUBTITLE

Weatherization of Residences: Criteria for Retrofit Materials and Products

5. $\operatorname{AUTHOR}(S)$

Walter J. Rossiter, Jr., Robert G. Mathey, editors

\begin{tabular}{|l|l}
\hline 6. PERFORMING ORGANIZATION (If joint or other than NBS, see instructions) & 7. Contract/Grant No.
\end{tabular}

NATIONAL BUREAU OF STANDARDS

DEPARTMENT OF COMMERCE

WASHINGTON, D.C. 20234

8. Type of Report \& Period Covered FINAL

9. SPONSORING ORGANIZATION NAME AND COMPLETE ADDRESS (Street. City, Stote, ZIP)

Department of Energy

Office of Weatherization Assistance

1000 Independence Avenue, S.W.

Washington, D.C. 20585

10. SUPPLEMENTARY NOTES

[] Document describes a computer program; SF-185, FIPS Software Summary, is attached.

11. ABSTRACT (A 200-word or less factual summary of most significant information. If document includes a significant bibliography or literature survey, mention it here)

The Department of Energy (DoE) requested the National Bureau of Standards to review and update criteria for materials and products to be included in the DoE Weatherization Assistance Program. This program was established by Congressional legislation in 1976 and was directed toward providing financial assistance to low-income individuals for retrofitting residences to conserve energy. In most cases, only energy-saving materials and products for which standards and specifications are available are to be included in the Program. In late 1983 DoE proposed rule changes to the Program which made it necessary to update existing criteria and establish, as appropriate, new criteria.

Criteria are given for retrofit materials and products included in the DoE Weatherizatin Assistance Program. These materials and products are thermal insulation, storm windows and doors, replacement windows and doors, caulks and sealants, weatherstripping, vapor retarders, clock thermostats, and replacement glazing. The criteria are based on a consideration of factors such as thermal performance, fire safety, durability, quality, conformance to building codes, use, and ease of installation.

The retrofit materials and products are listed by generic type along with pertinent standards and specifications. Precautions to be followed during their insulation are also given for each of the items. Fire safety requirements for thermal insulations are recommended with regard to the uSe and locations where they are installed.

12. KEY WORDS (Six to twelve entries; alphabetical order; capitalize only proper names; and separate key words by semicolons) caulks and sealants; clock thermostats; energy conservation; fire safety; insulation; replacement glazing; replacement windows and doors; retrofitting; storm windows and doors; vapor retarders; weatherization; weatherstripping.

13. AVAILABILITY

$\bar{X} \mathrm{X}$ Unlimited

$\square$ For Official Distribution. Do Not Release to NTIS XX Order From Superintendent of Documents, U.S. Government Printing Office, Washington, D.C.
20402 .

14. NO. OF PRINTED PAGES

68

Order From National Technical Information Service (NTIS), Springfield, VA. 2216I 



\section{Technical Publications}

\section{Periodicals}

Journal of Research-The Journal of Research of the National Bureau of Standards reports NBS research and development in those disciplines of the physical and engineering sciences in which the Bureau is active. These include physics, chemistry, engineering, mathematics, and computer sciences. Papers cover a broad range of subjects, with major emphasis on measurement methodology and the basic technology underlying standardization. Also included from time to time are survey articles on topics closely related to the Bureau's technical and scientific programs. As a special service to subscribers each issue contains complete citations to all recent Bureau publications in both NBS and non-NBS media. Issued six times a year. Annual subscription: domestic $\$ 18$; foreign $\$ 22.50$. Single copy, $\$ 5.50$ domestic; $\$ 6.90$ foreign.

\section{Nonperiodicals}

Monographs-Major contributions to the technical literature on various subjects related to the Bureau's scientific and technical activities.

Handbooks-Recommended codes of engineering and industrial practice (including safety codes) developed in cooperation with interested industries, professional organizations, and regulatory bodies.

Special Publications-Include proceedings of conferences sponsored by NBS, NBS annual reports, and other special publications appropriate to this grouping such as wall charts, pocket cards, and bibliographies.

Applied Mathematics Series-Mathematical tables, manuals, and studies of special interest to physicists, engineers, chemists, biologists, mathematicians, computer programmers, and others engaged in scientific and technical work.

National Standard Reference Data Series-Provides quantitative data on the physical and chemical properties of materials, compiled from the world's literature and critically evaluated. Developed under a worldwide program coordinated by NBS under the authority of the National Standard Data Act (Public Law 90-396).

NOTE: The Journal of Physical and Chemical Reference Data (JPCRD) is published quarterly for NBS by the American Chemical Society (ACS) and the American Institute of Physics (AIP). Subscriptions, reprints, and supplements are available from ACS, 1155 Sixteenth St., NW, Washington, DC 20056.

Building Science Series-Disseminates technical information developed at the Bureau on building materials, components, systems, and whole structures. The series presents research results, test methods, and performance criteria related to the structural and environmental functions and the durability and safety characteristics of building elements and systems.

Technical Notes-Studies or reports which are complete in themselves but restrictive in their treatment of a subject. Analogous to monographs but not so comprehensive in scope or definitive in treatment of the subject area. Often serve as a vehicle for final reports of work performed at NBS under the sponsorship of other government agencies.

Voluntary Product Standards-Developed under procedures published by the Department of Commerce in Part 10, Title 15, of the Code of Federal Regulations. The standards establish nationally recognized requirements for products, and provide all concerned interests with a basis for common understanding of the characteristics of the products. NBS administers this program as a supplement to the activities of the private sector standardizing organizations.

Consumer Information Series-Practical information, based on NBS research and experience, covering areas of interest to the consumer. Easily understandable language and illustrations provide useful background knowledge for shopping in today's technological marketplace.

Order the above NBS publications from: Superintendent of Documents, Governinent Printing Office, Washington, DC 20402.

Order the following NBS publications-FIPS and NBSIR's-from the National Technical Information Service, Springfield, VA 22161.

Federal Information Processing Standards Publications (FIPS PUB)_-Publications in this series collectively constitute the Federal Information Processing Standards Register. The Register serves as the official source of information in the Federal Government regarding standards issued by NBS pursuant to the Federal Property and Administrative Services Act of 1949 as amended, Public Law 89-306 (79 Stat. 1127), and as implenented by Executive Order 11717 (38 FR 12315, dated May 11, 1973) and Part 6 of Title 15 CFR (Code of Federal Regulations).

NBS Interagency Reports (NBSIR)-A special series of interim or final reports on work performed by NBS for outside sponsors (both government and non-government). In general, initial distribution is handled by the sponsor; public distribution is by the National Technical Information Service, Springfield, VA 22161, in papel copy or microfiche form. 
U.S. Department of Commerce National Bureau of Standards

Gaithersburg, MD 20899

Official Business

Penalty for Private Use $\$ 300$ 